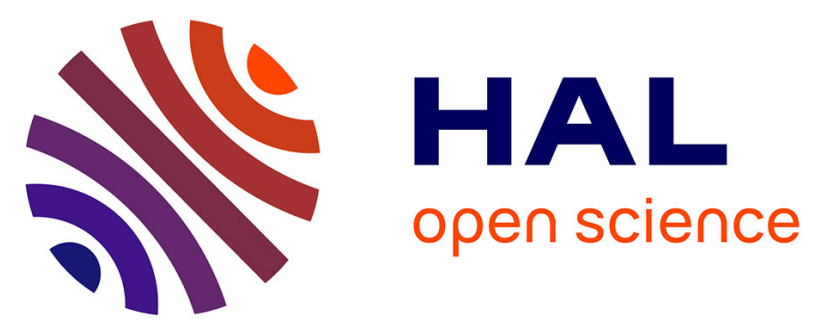

\title{
Burma Terrane collision and northward indentation in the Eastern Himalayas recorded in the Eocene - Miocene Chindwin Basin (Myanmar)
}

Jan Westerweel, Alexis Licht, Nathan Cogné, Pierrick Roperch, Guillaume Dupont-Nivet, Myat Kay Thi, Hnin Hnin Swe, Huasheng Huang, Zaw Win, Day Wa Aung

\section{To cite this version:}

Jan Westerweel, Alexis Licht, Nathan Cogné, Pierrick Roperch, Guillaume Dupont-Nivet, et al.. Burma Terrane collision and northward indentation in the Eastern Himalayas recorded in the Eocene - Miocene Chindwin Basin (Myanmar). Tectonics, 2020, 39 (10), pp.e2020TC006413. 10.1029/2020TC006413 . insu-02968719

\section{HAL Id: insu-02968719}

\section{https://hal-insu.archives-ouvertes.fr/insu-02968719}

Submitted on 21 Oct 2020

HAL is a multi-disciplinary open access archive for the deposit and dissemination of scientific research documents, whether they are published or not. The documents may come from teaching and research institutions in France or abroad, or from public or private research centers.
L'archive ouverte pluridisciplinaire HAL, est destinée au dépôt et à la diffusion de documents scientifiques de niveau recherche, publiés ou non, émanant des établissements d'enseignement et de recherche français ou étrangers, des laboratoires publics ou privés. 


\section{Tectonics}

\author{
RESEARCH ARTICLE \\ 10.1029/2020TC006413 \\ Key Points: \\ - The Eocene to Lower Miocene \\ sedimentary infill of the Chindwin \\ forearc basin of the Burma Terrane \\ is punctuated by two major \\ unconformities \\ - The first late Eocene-middle \\ Oligocene unconformity records the \\ initial collision of India and the \\ northern Burma Terrane with Asia \\ - The second late Oligocene-early \\ Miocene unconformity marks major \\ deformation in the Eastern \\ Himalayas due to Burma Terrane \\ northward motion
}

Supporting Information:

- Supporting Information S1

- Figure S1

- Figure S2

- Figure S3

- Figure S4

- Table S1

- Table S2

- Table S3

Correspondence to:

J. Westerweel,

jan.westerweel@univ-rennes1.fr

\section{Citation:}

Westerweel, J., Licht, A., Cogné, N., Roperch, P., Dupont-Nivet, G., Kay Thi, M., et al. (2020). Burma Terrane collision and northward indentation in the Eastern Himalayas recorded in the Eocene-Miocene Chindwin Basin (Myanmar). Tectonics, 39, e2020TC006413. https://doi.org/ 10.1029/2020TC006413

Received 19 MAR 2020 Accepted 24 SEP 2020 Accepted article online 5 OCT 2020

(C)2020. American Geophysical Union. All Rights Reserved.

\section{Burma Terrane Collision and Northward Indentation in the Eastern Himalayas Recorded in the Eocene-Miocene Chindwin Basin (Myanmar)}

\author{
Jan Westerweel $^{1}$ D , Alexis Licht ${ }^{2}$ iD, Nathan Cogné $^{1}$ (D) Pierrick Roperch ${ }^{1}$, \\ Guillaume Dupont-Nivet ${ }^{1,3}$ (D), Myat Kay Thi ${ }^{4}$, Hnin Hnin Swe ${ }^{4}$, Huasheng Huang ${ }^{5}$, \\ Zaw Win 6 , and Day Wa Aung ${ }^{4}$
}

${ }^{1}$ Geosciences Rennes, CNRS, University Rennes, Rennes, France, ${ }^{2}$ Department Earth and Space Sciences, University of Washington, Seattle, WA, USA, ${ }^{3}$ Department of Geociences, Potsdam University, Potsdam, Germany, ${ }^{4}$ Department of Geology, University of Yangon, Yangon, Myanmar, ${ }^{5}$ Institute for Biodiversity and Ecosystem Dynamics, University of Amsterdam, Amsterdam, The Netherlands, ${ }^{6}$ Department of Geology, University of Shwebo, Shwebo, Myanmar

\begin{abstract}
The Burma Terrane (Myanmar) played an important role in the India-Asia collision and moved over 2,000 km northward on the Indian Plate during the Cenozoic, before colliding with the Asian margin. However, the timing of this collision and its correlation to regional uplift phases, sedimentary provenance, and basin development remain poorly constrained. We report sedimentological, paleomagnetic, and geochronological data from the late Eocene to early Miocene strata of the Chindwin Basin in the Burmese forearc, constraining the paleogeographic evolution of the Burma Terrane and the Eastern Himalayan orogen. Our results highlight two unconformities of late Eocene-middle Oligocene and latest Oligocene-early Miocene age, revealing a two-stage interaction of the Burma Terrane with the Asian margin during its northward translation. The first unconformity follows rapid $\sim 0.6 \mathrm{~m} / \mathrm{ky}$ subsidence in the Burmese forearc, as shown by magnetostratigraphy. The transition to a fluvial depositional environment and the occurrence of reworked sediments at this first unconformity likely records the commencing collision of India and the northern extent of the Burma Terrane with the Asian margin. The second unconformity shows drastic changes in magnetic properties, mineralogy, and provenance, with high-grade metamorphic grains and early Miocene apatite U-Pb and fission-track ages indicating that it is coeval to a major deformation phase in Myanmar and the Eastern Himalayan orogen. It likely records the indentation of the Burma Terrane into the Eastern Himalayan collision zone, forming the modern Eastern Himalayan Syntaxis.
\end{abstract}

Plain Language Summary The evolution of the India-Asia collision and the resulting formation of the dramatic Himalayan mountain chain are highly debated among geologists. One of the reasons is that the easternmost extent of this mountain range is understudied compared to its central part. In Myanmar, at the eastern end of the Himalayas, this is partly caused by political and scientific isolation over the past 70 years, limited road access, and jungle covering much of the exposure. This study helps to constrain the paleogeographic evolution of the Burma Terrane, the microplate including most of Myanmar. To this end, we used a variety of methods including describing sedimentary deposits of the Burma Terrane, dating these deposits and determining their corresponding source regions. With this new information, we were able to determine that the deposition of these sediments occurred from $\sim 40$ to 23 million years ago but was discontinuous with two large hiatuses of millions of years long. Our results show that these two hiatuses are a consequence of a two-stage process during the large northward motion of the Burma Terrane involving (1) the first collision of India and the northern Burma Terrane with Asia and (2) the indentation of Burma into the Himalayan collision zone.

\section{Introduction}

The Himalayan-Tibetan orogen, formed primarily as a result of the India-Asia collision, is widely recognized as the archetype orogen for studying the evolution of continent-continent collision systems. Its complex geodynamic history and profound influence on Asian paleoenvironments and climate have been described by a diversity of studies (Dupont-Nivet et al., 2007; Kapp \& DeCelles, 2019; Licht, van Cappelle, et al., 2014; 
Royden et al., 2008; Yin \& Harrison, 2000). Yet the paleogeographic evolution of the Asian margin during the convergence of India and Asia, as well as the timing of the collision itself, remain subject to debate (e.g., Hu et al., 2015; Jagoutz et al., 2015; Replumaz et al., 2010, 2013; Royden et al., 2008; Shen et al., 2001; van Hinsbergen et al., 2011, 2018; Westerweel et al., 2019). An important reason behind this ongoing debate is that the $\sim 1,500 \mathrm{~km}$ long eastern extent of the Himalayas in Myanmar remains understudied compared to the central orogen in terms of timing of tectonic events, sedimentary sourcing and roles of different tectonic terranes, resulting in a substantial spatial gap in our understanding of the India-Asia collision.

This is best illustrated by the Burma Terrane (BT, also called West Burma Block), a major tectonic terrane comprising most of Myanmar. Fundamental aspects of the geological history of the BT remain debated, despite it being key to the geodynamic evolution of the India-Asia collision (Licht et al., 2019; Westerweel et al., 2019). Since the Neogene, its unique tectonic regime (Figure 1a) is characterized by hyper-oblique subduction of the Indian Plate beneath the Burmese active margin to the west, causing sporadic volcanism along the Wuntho-Popa Arc (WPA; Lin et al., 2019; Mitchell et al., 2012). In addition, it induced large-scale dextral strike-slip displacements along the Sagaing Fault bounding the BT to the east, resulting in a northward transcurrent motion of the BT (Bertrand \& Rangin, 2003; Mitchell et al., 2012; Morley, 2017; Morley et al., 2020; Morley \& Arboit, 2019; Rangin, 2018; Rangin et al., 2013; Socquet et al., 2006).

Recent paleorotation and paleolatitude data from paleomagnetism indicate that the BT was part of a nearequatorial, isolated Trans-Tethyan Arc from the Late Cretaceous to the early Paleogene when India collided with this Trans-Tethyan Arc (Westerweel et al., 2019). The paleomagnetic data also show that since the late Eocene, the BT underwent over 2,000 km of northward translation alongside India from a near-equatorial position (Westerweel et al., 2019). To the east, strike-slip motion along the Sagaing Fault, a precursor thereof, or an India-Australia Transform separated the BT from the Indochina margin (Morley et al., 2020; Morley \& Arboit, 2019). This significant northward translation moved the BT from near-equatorial latitudes toward the Eastern Himalayan collision zone. However, crucial questions such as the location and timing of indentation of the BT into the collision zone and subsequent underthrusting, its interaction with India, as well as the relation of these events to regional phases of uplift and exhumation remain unanswered within this new tectonic context. Furthermore, the new tectonic context requires a re-evaluation of the provenance of the Cenozoic sedimentary basins within the BT, because it shows that the BT was potentially isolated from sedimentary sources in Asia and Indochina until the Eocene to Oligocene (Morley et al., 2020; Westerweel et al., 2019).

In this paper, we study the Cenozoic sedimentary record of the Burmese forearc to constrain changes in tectonic setting, sedimentary provenance and paleoenvironment during the $\sim 2,000 \mathrm{~km}$ northward journey from the equator toward the collision zone. To constrain the interaction of the BT with Asia and India, we investigated a $\sim 2$-km-thick Eocene to Oligocene sedimentary section in the Chindwin Basin, northwestern Myanmar, using results from sedimentology, magnetostratigraphy, magnetic properties, and zircon $\mathrm{U}-\mathrm{Pb}$, apatite $\mathrm{U}-\mathrm{Pb}$, and apatite fission-track (AFT) dating. Our results enable us to evaluate the plate tectonic and paleogeographic evolution of the Eastern Himalayan collision zone.

\section{Geological Setting}

Traditionally, the geology of Myanmar is subdivided into three broad N-S trending regions: the Indo-Burman Ranges (IBR), the BT, and the Shan Plateau on the Sibumasu Block. In northern Myanmar, these regions extend into the Eastern Himalayan orogen.

\subsection{The BT}

The BT forms the bulk of western and central Myanmar. Known basement units of the BT only crop out in the IBR and in the Wuntho Ranges, the predominantly Mesozoic volcanic complex forming the northern segment of the WPA (Mitchell, 2017; United Nations, 1978). Northeast of the Wuntho Ranges, the serpentinites, and jadeites of the Jade Belt are only exposed at the northern edge of the Sagaing Fault (Figure 1a) and have a poorly constrained emplacement age (Searle et al., 2017; Yui et al., 2013). East of the Jade Belt, the Tagaung-Myitkyina Belt comprises Triassic to Jurassic metasedimentary rocks and Jurassic to Cretaceous volcanics (Mitchell, 2017), notably the $\sim 50$ Ma Sodon Batholith that has been correlated with the WPA (Lin et al., 2019). 


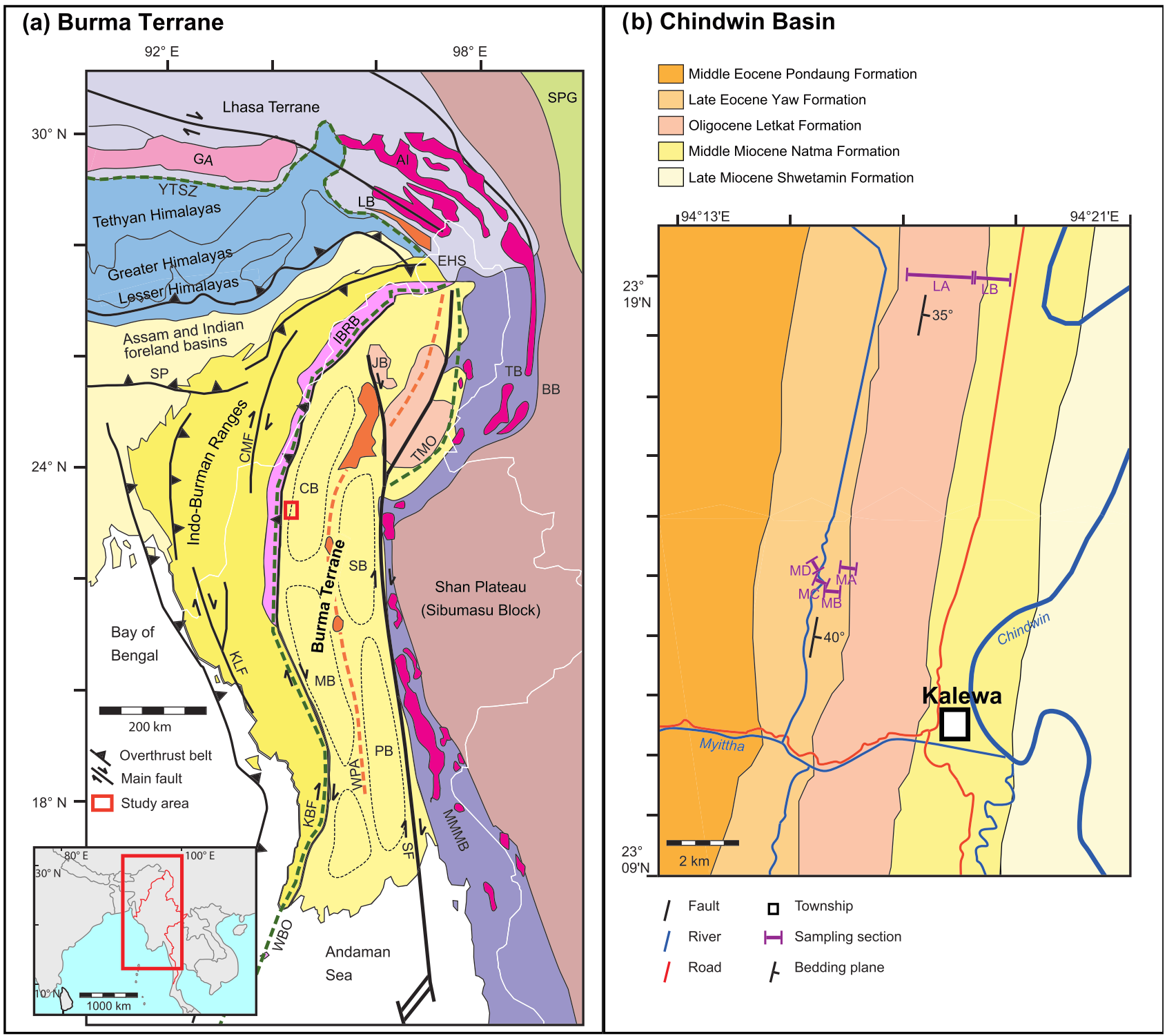

Figure 1. (a) Geological map of Myanmar and surrounding regions. Abbreviations: $\mathrm{AI}=$ Cretaceous-Paleogene Asian intrusives, $\mathrm{BB}=\mathrm{Baoshan}$ Block, $\mathrm{CB}=$ Chindwin Basin, $\mathrm{CMF}=$ Churachandpur Mao Fault, EHS $=$ Eastern Himalayan Syntaxis, GA $=$ Cretaceous Gangdese Arc, IBRB $=$ Indo-Burman Ranges basement, JB = Jade Belt, KBF = Kabaw Fault, KLF = Kaladan Fault, LB = Lohit Batholith, MB = Minbu Basin, MMMB = Mogok-Mandalay-Mergui Belt $\mathrm{PB}=$ Pegu Basin, $\mathrm{SB}=$ Shwebo Basin, SF = Sagaing Fault, SP = Shilong Plateau, SPG = Songpan Ganze and Yangtze complexes, TB = Tengchong Block, TMO = Tagaung-Myitkyina Ophiolite, WBO = Cretaceous Western Belt Ophiolite, WPA = Wuntho-Popa Arc, YTSZ = Yarlung Tsangpo Suture Zone. Dashed black lines: Central Myanmar Basins. (b) Geological map of the study area around Kalewa in the Chindwin Basin (after Westerweel et al., 2019).

The Sagaing Fault and Mogok-Mandalay-Mergui Belt (MMMB) form the boundary of the BT with the Shan Plateau, Sibumasu (Figure 1a). The MMMB is a metamorphic belt forming the southeast continuation of the pre-collision Asian margin. The most prominent rocks of the MMMB include Cretaceous-Cenozoic intrusives with generally negative $\varepsilon H f(t)$ values, as well as regionally metamorphosed ophiolitic and sedimentary rocks (Gardiner et al., 2018; Lin et al., 2019; Mitchell, 2017; Mitchell et al., 2012; Searle et al., 2017). The MMMB records two main metamorphic events: A latest Cretaceous-early Paleocene phase of metamorphism and partial melting, followed by a phase of high temperature metamorphism during the late EoceneOligocene, suggested to be related to the India-Asia collision (Searle et al., 2007, 2017, 2020). Low temperature thermochronometers show a late Eocene-Miocene phase of rapid exhumation related to the strike-slip deformation and extrusion of the MMMB (Bertrand et al., 2001; Bertrand \& Rangin, 2003). Plate 
reconstructions suggest that the MMMB, including the Tengchong and Baoshan blocks, was extruded from the Eastern Himalayan Syntaxis toward the southeast since approximately the late Paleogene (Li et al., 2018; Tong et al., 2013; Westerweel et al., 2019).

The Burmese subduction margin, located west of the BT, formed during the mid-Cretaceous as evidenced by emplacement of the Naga Hills-Kaleymyo-Andaman Ophiolitic belt (also called the Western Belt Ophiolite; Figure 1a; Fareeduddin \& Dilek, 2015; Licht et al., 2019; Morley et al., 2020; Pivnik et al., 1998; Singh et al., 2016). This was followed by early Late Cretaceous Andean-type magmatism in the WPA. The near-equatorial latitudes from paleomagnetic data from the early Late Cretaceous WPA rocks imply that the BT was part of a Trans-Tethyan Arc at that time (Westerweel et al., 2019). Magmatic activity in the WPA peaked at $~ 110-90 \mathrm{Ma}$, followed by a 70-40 Ma subordinate stage indicating a decrease in activity (Barley \& Zaw, 2009; Gardiner et al., 2017; Mitchell et al., 2012; Wang et al., 2014; Zhang et al., 2017). The WPA rocks are today exposed in the Wuntho Ranges, where only the $110-90$ Ma stage and a minor peak in volcanic activity at 42-36 Ma are present (Barley \& Zaw, 2009; Gardiner et al., 2017; Licht et al., 2020; Lin et al., 2019). The remaining part of the WPA is covered by Cenozoic sediments. The Paleogene sequence of this sedimentary cover was partially eroded during a subsequent Oligocene phase of exhumation, as shown by a large angular unconformity in seismic lines across the WPA (Zhang et al., 2017).

\subsection{Indo-Burman Ranges}

The Western Belt Ophiolite and the Kabaw Fault form the western boundary separating the BT from the IBR (Figure 1a; Liu et al., 2016; Mitchell et al., 2012; Morley et al., 2020; Searle et al., 2017). The IBR constitute an accretionary complex formed by subduction of the Indian Plate, separating the BT from the Indian Foreland Basins and Bay of Bengal (Rangin, 2018). The IBR are divided into an Outer Wedge and an Inner Wedge (Bannert et al., 2012; Brunnschweiler, 1966; Maurin \& Rangin, 2009; Mitchell, 2017). The Outer Wedge consists of a predominantly Neogene fold and thrust belt deforming the sediments of the Bengal fan with Himalayan affinity (Betka et al., 2018; Najman et al., 2012; Rangin, 2018; Steckler et al., 2008).

The geology and deformation history of the Inner Wedge are more complex compared to the Outer Wedge. The oldest basement units in the Inner Wedge (Triassic Pane Chaung Formation and Kanpetlet Schists) are covered by a sequence of Upper Cretaceous-Eocene marine turbiditic rocks (Bannert et al., 2012; Maurin \& Rangin, 2009; Mitchell, 2017). These turbiditic rocks are unconformably overlain by late Eocene-early Oligocene molasse deposits, indicating an initial uplift phase within the IBR at that time (Bannert et al., 2012; Ghose et al., 2014; Morley et al., 2020). The IBR turbiditic rocks share the same petrography and zircon U-Pb age distributions as coeval sediments in the Burmese forearc basin, indicating both have similar source regions, likely including the WPA (Licht et al., 2019; Naing et al., 2014; Najman et al., 2020; Wang et al., 2014). By contrast, more recent Neogene sediments in the IBR were likely supplied by Himalayan sources or uplifting IBR basement (Naing et al., 2014; Najman et al., 2020). Recent low temperature thermochronological data documented a major exhumation phase within the IBR during the latest Oligocene-earliest Miocene, and a possible earlier event in the late middle Eocene (Najman et al., 2020). Changes of sedimentary facies in the late middle Eocene in the forearc basin, indicating the onset of wide barrier-bound estuaries, were interpreted as reflecting incipient IBR uplift (Licht et al., 2019).

There are differing interpretations on the cause for these uplift phases. It has been proposed that late middle Eocene uplift of the IBR was the result of coupling with India (Aitchison et al., 2007; Morley, 2009; Morley et al., 2020; Vérard et al., 2017) or an allochthonous terrane (Acharyya, 2007, 2015). Other studies have argued that the uplift of the Inner Wedge was induced by the rapidly uplifting retro-wedge region of the IBR formed due to hyper-oblique subduction (Licht et al., 2019; Maurin \& Rangin, 2009; Nielsen et al., 2004). Major strike-slip deformation in the IBR occurred since the Neogene, illustrated by the initiation of major dextral faults such as the (South) Kabaw, Kaladan, and Churachandpur Mao Faults (Maurin \& Rangin, 2009; Morley et al., 2020; Rangin, 2018).

\subsection{Eastern Himalayan Orogen}

To the north, the transition from the BT to the Eastern Himalayan orogen is defined by the intersection of the Sagaing Fault and the IBR (Lin et al., 2019; Mitchell, 2017; Mitchell et al., 2012). However, it is unclear how much of the northern extension of the BT (i.e., Greater Burma) was shortened, subducted, and underthrust in the Eastern Himalayan Syntaxis during its northward motion (Haproff et al., 2019, 
2020; Morley et al., 2020; Westerweel et al., 2019). At present, the orogen bends from $\sim \mathrm{E}-\mathrm{W}$ to $\sim \mathrm{NW}-\mathrm{SE}$ at the Eastern Himalayan Syntaxis (Figure 1a). Prominent lithologies in the Eastern Himalayan Syntaxis directly north of the BT include deformed metamorphosed rocks such as gneiss and schist, ophiolitic mélange, and (meta)sediments and volcanic complexes such as the Late Jurassic-Cretaceous I-type Lohit Batholith and the Jurassic-Cretaceous S-type Bomi-Chayu Batholith (Haproff et al., 2019; Lin et al., 2019). Many of the intrusive units in the Eastern Himalayan orogen have also been correlated with similar lithologies in Myanmar to the (south-)east based on age and $\varepsilon H f(t)$ values, notably the Bomi-Chayu Batholith with the Dianxi Batholith in the MMMB or the Lohit Batholith with the WPA (Lin et al., 2019; Mitchell et al., 2012). Important deformation phases in the Eastern Himalayan orogen include an early Miocene phase of uplift and exhumation, as recorded by 20-15 Ma activity along the Lohit thrust (Haproff et al., 2019). This corresponds to a 23-16 Ma phase of uplift and exhumation of the Greater Himalayas across the entire Himalayan orogen (Garzanti, 2019; Vannay et al., 2004). Additional rapid exhumation at $14-17 \mathrm{Ma}$ is reported from the Greater Himalayas along the Main Central Thrust in the Eastern Himalayan Syntaxis (Godin et al., 2006; Kellett et al., 2013; Najman et al., 2019). This early Miocene deformation phase led to the set-up of the modern Eastern Himalayan Syntaxis, which sources the Yarlung Tsangpo Brahmaputra River flowing toward the Bay of Bengal (Bracciali et al., 2015). Finally, this was followed by the intense late Miocene-Pliocene exhumation phases in the Eastern Himalayan Syntaxis core (Bracciali et al., 2016; Lang et al., 2016; Najman et al., 2019; van der Beek et al., 2019; Zeitler et al., 2014).

\subsection{Central Myanmar Basins}

The Central Myanmar Basins (CMB) on the BT developed as early as the Albian in forearc and backarc positions, subdivided by the WPA (Figure 1a; Bender, 1983; Cai et al., 2019; Licht et al., 2019; Pivnik et al., 1998; Zhang et al., 2017). Seismic lines across the CMB show four regional unconformities, interpreted to reflect deformation phases attributed to the Late Cretaceous, late Eocene, Oligocene, and late Miocene (Pivnik et al., 1998; Zhang et al., 2017). The Oligocene unconformity is particularly well expressed (Rangin, 2018; Zhang et al., 2017). Most basins experienced tectonic inversion starting in the late Miocene (Bertrand \& Rangin, 2003; Pivnik et al., 1998; Rangin, 2018; Zhang et al., 2017).

The Burmese backarc consists of the Shwebo Basin in the north and the Pegu Basin in the south (Figure 1a). The Paleogene deposits in the Shwebo Basin are exclusively continental with southward prograding fluvio-deltaic sequences (Thein \& Maung, 2017), while those in the Pegu Basin have not been described. Since the Neogene, both basins were characterized by southward prograding tidal-influenced estuarian sequences, before being overlain by fluvial deposits of the Quaternary Irrawaddy Formation (Bender, 1983; Khin, 1999; Pivnik et al., 1998; Thein \& Maung, 2017). The Burmese forearc basins are commonly subdivided into the Minbu (or Salin) Basin in the south, which has been relatively well documented due to its hydrocarbon potential (Pivnik et al., 1998), and the less well-documented Chindwin Basin in the north (Figure 1a). The Burmese forearc basins are subject of this study and their geology will be described in further detail below.

\subsubsection{The Minbu Basin}

East of the IBR and west of the WPA, the Minbu Basin (Figure 1) constitutes the southern Burmese forearc basin separated from the Chindwin Basin by a small topographic high called the Pondaung Ranges (Bender, 1983; Licht et al., 2019; Pivnik et al., 1998; Zhang et al., 2017). The sedimentary sequence of the Minbu Basin (Figure 2) begins with the poorly exposed marine sediments of the Albian to Maastrichtian Kabaw Formation (Bender, 1983; Cai et al., 2019). This is followed by a Paleocene to middle Eocene sequence of shallow-marine siliciclastics alternating with sporadic continental deposits, consisting of the Paunggyi, Laungshe, Tilin, and Tabyin Formations with poorly defined lithostratigraphic boundaries (Bender, 1983; Licht et al., 2019). This sequence is followed by the middle to upper Eocene Pondaung Formation, which is made of fluvio-deltaic sediments and has been dated at 40 Ma (Jaeger et al., 1999; Licht, Cojan, et al., 2014; Licht et al., 2015; Zaw et al., 2014). It is overlain by the upper Eocene Yaw Formation consisting of shallow-marine sediments. All subsequent Oligocene formations in the Minbu Basin, the Shwezetaw, Padaung, and Okhmintaung Formations are continuous and consist of fluvio-deltaic to predominantly marine facies toward the south (Bender, 1983; Gough et al., 2020). This sequence is covered by the lower and middle Miocene fluvio-deltaic deposits of the Pyawbwe, Kyaukkok and Obogon Formations; the sequence is 
Forearc Basin

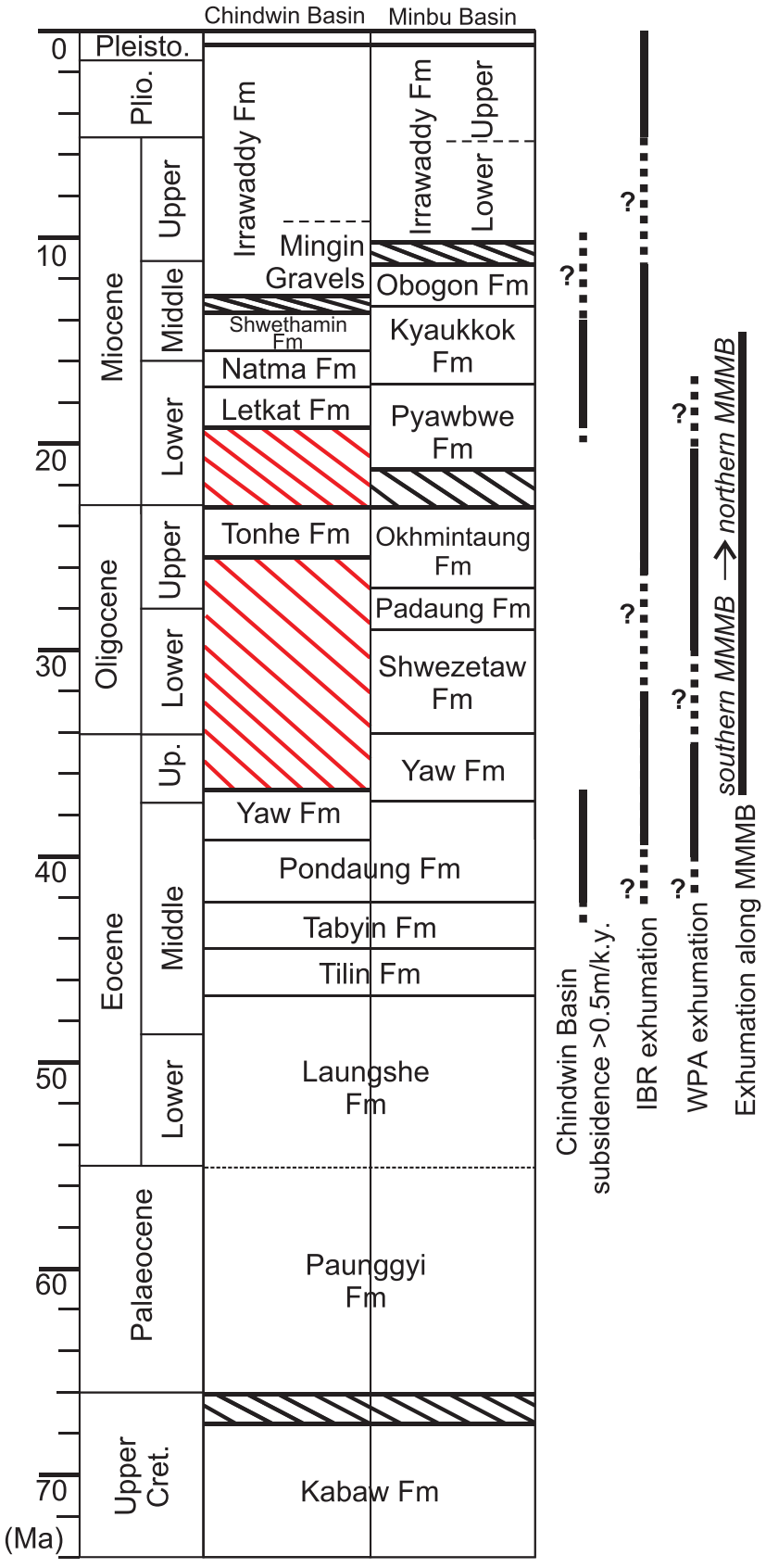

Figure 2. Synthetic log of the Chindwin Basin (modified from Licht et al., 2019 based on our new magnetostratigraphic and geochronological constraints) and Minbu Basin (after Cai et al., 2019; Zhang et al., 2019), compared to periods of rapid subsidence in the Chindwin Basin ( $>0.5 \mathrm{~m} / \mathrm{ky}$; after Licht et al., 2019; this study), the timing of uplift in the Indo-Burman Ranges (IBR; after Licht et al., 2019; Morley et al., 2020; Najman et al., 2020), WPA (Wuntho-Popa Arc; after Zhang et al., 2017), and Mogok-Mandalay-Mergui Belt (MMMB; after Bertrand et al., 2001).

Unconformities constrained by this study are highlighted in red. finally capped by the middle Miocene-Pliocene Irrawaddy Formation, which covers most lowlands of the CMB.

\subsubsection{The Chindwin Basin}

The depositional history of the Chindwin Basin is similar to that of the Minbu Basin up until the upper Eocene Yaw Formation. By contrast to the Minbu Basin, the Yaw Formation in the Chindwin Basin comprises four distinct sedimentary facies (Figure 3; Licht et al., 2019). These are anoxic sediments containing organic-rich dark mudstones and siderite-rich carbonate layers (FA1), deltaic tidal sand flat sediments (FA2), and finally continental deposits with thick fluvial sandstone bodies (FA3) and thick lignite layers containing vertebrate fossils (FA4). Paleocurrents measured in FA3 have an average direction toward the WSW. The combination of these four sedimentary facies was interpreted as a quasi-closed estuarian system, sustained primarily by tectonic uplift of the IBR (Licht et al., 2019). A single tuff layer is also present in the Yaw Formation, yielding a U-Pb age constraint of $38.3 \pm 1.1 \mathrm{Ma}$ (Licht et al., 2019), consistent with palynological results (Huang et al., 2020).

The Yaw Formation is overlain by $6 \mathrm{~km}$ of coarse fluviatile facies, divided into the Tonhe, Letkat, Natma, Shwethamin, and Irrawaddy Formations (Bender, 1983). The Tonhe Formation consists of thick packages of particularly coarse gravel and sand beds with thick sets of planar bedding and trough cross-bedding, alternating with paleosols (Figures 3 and 4). It has yielded an abundant Oligocene pollen assemblage (Lwin et al., 2017), including Florschuetzia semilobata that suggests an upper Oligocene age (R. Morley, pers. com.). The subsequent Letkat, Natma, and Shwethamin Formations consist of afossiliferous fluviatile sandstones and pedogenised finer-grained sands and mudstones (Licht et al., 2019). Paleocurrents in the sandstones of the Letkat Formation cover a broad range of directions with an average SSW direction (Licht et al., 2019). The upper part of the Letkat Formation has yielded detrital zircons as young as 23-17 Ma, indicating a lower Miocene age or younger (Licht et al., 2019; Wang et al., 2014). The base of the Irrawaddy Formation, also named Mingin Gravels in the southern Chindwin Basin, has yielded fossil mammals indicating a middle Miocene (14-11 Ma) age, coeval to the Chinji fauna of Pakistan (Bender, 1983).

Recent studies have suggested that the diverging stratigraphic record between both forearc basins was caused by the onset of hyper-oblique convergence at $~ 39-37 \mathrm{Ma}$, which resulted in the development of en echelon pull-apart basins (Licht et al., 2019). The coeval motion of India and the BT from paleomagnetic data suggest that most strike-slip displacements were concentrated east of the BT at that time (Westerweel et al., 2019). The Chindwin Basin is interpreted as a pull-apart basin partly due to rapid subsidence $(\sim 1.0 \mathrm{~m} / \mathrm{ky})$ during deposition of the Yaw Formation (Licht et al., 2019). Around this time, there was also a change from primarily volcanic arc provenance in the Pondaung and Yaw Formations to increasingly more input of metamorphic grains, possibly derived from MMMB basement rocks (Licht et al., 2013, 2019; Wang et al., 2014).

\section{Methods}

\subsection{Sedimentology}

During five consecutive field seasons between 2015 and 2019, we described deposits along a north-south trending portion of the Chindwin Basin north 


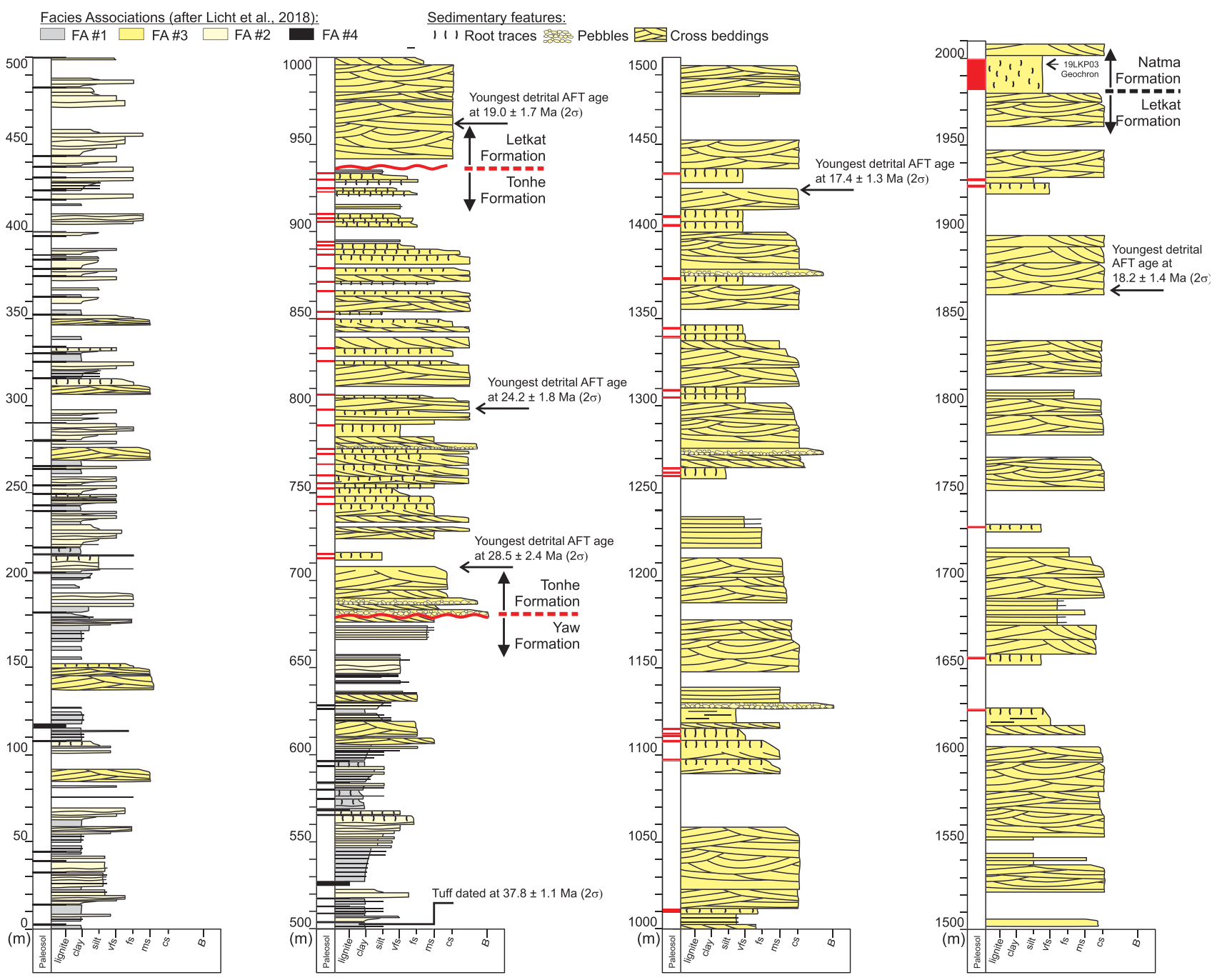

Figure 3. Composite log of the investigated section in this study, including the upper part of the Yaw Formation, the Tonhe Formation, and the Letkat Formation. The first $~ 1,450 \mathrm{~m}$ of this section was already logged by Licht et al. (2019); during this study, it was extended upward for $~ 535 \mathrm{~m}$ and reinterpreted to include the Tonhe Formation and two major unconformities (highlighted in red). Relevant maximum depositional ages from sandstone samples and age of the tuff layer redated in this study are also shown (cf. Table S1). In the Paleosol column, black lines indicate histosols whereas red lines indicate ultisols and vertisols. vfs—very fine sand; fs—fine sand; ms—-medium sand; cs—coarse sand; B-Boulder.

of the Kalewa Township (Figure 1b). Additionally, we used a composite section spanning the Yaw, Tonhe, and Letkat Formations, composed of six stratigraphic sections (Figure 1b; from bottom to top: MD, MC, MB, MA, LA, and LB sections). The five stratigraphic sections spanning $~ 1,450 \mathrm{~m}$ of the Yaw Formation, the Tonhe Formation, and the base of the Letkat Formation (sections MD, MC, MB, MA, and LA) have already been published, together with details on sedimentary facies (Licht et al., 2019). Here, we extend our $\log$ by an additional $535 \mathrm{~m}$ covering the entire Letkat Formation up to the base of the Natma Formation (section LB), measured at $\sim 1 \mathrm{~m}$ resolution. We also distinguish between the Tonhe and Letkat Formations, which were treated as a single unit in Licht et al. (2019). Detailed logs are available in Figure S1 in the supporting information and are combined into a composite log in Figure 3.

\subsection{Rock Magnetism}

Paleomagnetic sampling was conducted in the lower $\sim 1,450 \mathrm{~m}$ of the composite stratigraphic section, yielding 582 conventional paleomagnetic core plug samples for magnetostratigraphy. In addition, 63 hand samples were obtained from the Letkat Formation (LA section) up until the top of the section ( 940-1925 m) 

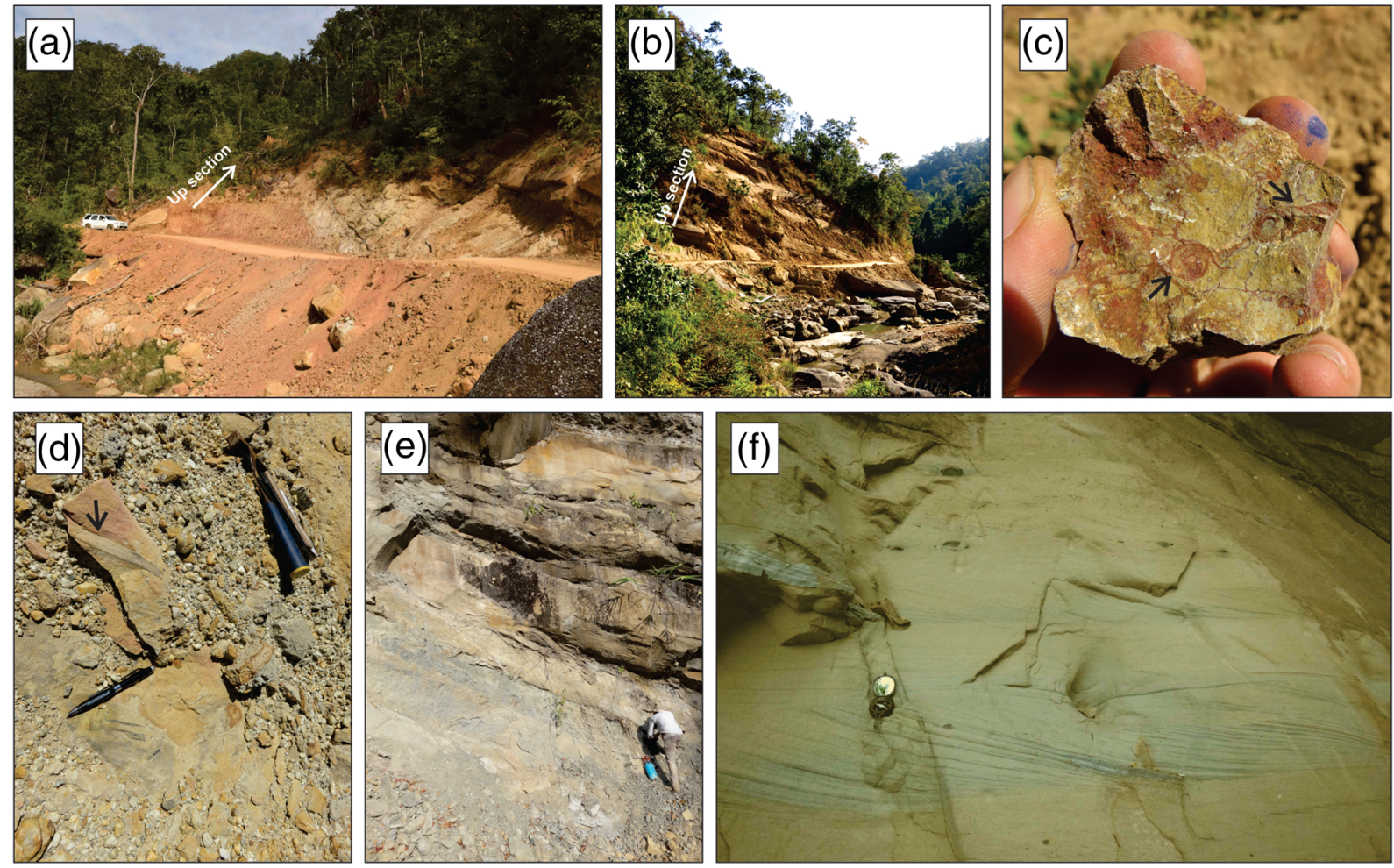

Figure 4. Relevant sedimentological observations from this study: (a and b) alternation of reds beds and gravel beds in the Tonhe Formation; (c) red mottles and trace fossils Naktodemasis sp. (black arrows) in red beds of the Tonhe Formation; (d) quartz gravels and tree stem print (black arrow) in sandstones of the Tonhe Formation; and (e and f) coarse sandstones of the Letkat Formation, with organic matter in the foresets. When the scale is not displayed, rock hammers, pencils, compass, cars, and humans can be used for scale.

(Table S1). The magnetic properties of the different lithologies within the logged sequence were investigated and compared with petrologic and mineralogic observations from thin sections.

Before demagnetization, the volume-corrected bulk magnetic susceptibility of every sample was measured and plotted alongside the (magneto)stratigraphic results to constrain differences in magnetic properties and mineralogy. Their anisotropy of magnetic susceptibility (AMS) was determined on a KLY3S AGICO kappabridge to investigate the magnetic fabric. The AMS tensor could potentially be used to determine a paleocurrent, if samples have strong anisotropy controlled by sedimentary deposition under high current flow (Tauxe, 2010). However, in compressive regimes, the maximum axis $K_{\max }$ of the AMS tensor will gradually be aligned perpendicular to the direction of maximum compression (Kissel et al., 1986). Even an incipient tectonic shortening creates a magnetic lineation parallel to fold axes (layer parallel shortening) that usually fully overprints paleocurrent information.

To gain more insight into magnetic properties and mineralogy of the different units, additional types of experiments were conducted for a selection of samples. Firstly, mass-corrected bulk magnetic susceptibility versus temperature $(K-T)$ plots were obtained by measuring the mass-corrected bulk magnetic at increasing temperature steps up to $580^{\circ} \mathrm{C}$ on a KLY3-CS3 AGICO kappabridge for different lithologies. Isothermal remanent magnetization (IRM) acquisition was done up until 2,400 $\mathrm{mT}$ for different samples to constrain differences in grain size and content. Finally, we measured several magnetic hysteresis loops on an AGM magnetometer.

To further investigate magnetic properties of the various lithologies by identifying their (magnetic) mineralogy, polished thin sections were made from selected samples for observation under an optical microscope in both transmitted light and reflected light. Samples were also analyzed with a scanning electron microscope (SEM-JEOL JSM 7100F with energy-dispersive X-ray spectroscopy, Oxford EDS/EBSD) at Geosciences Rennes. Additional petrology (e.g., grain counting) was already done in the preceding study from the same stratigraphic section (Licht et al., 2019). 


\subsection{Paleomagnetic Analysis}

Orientation of 582 conventional paleomagnetic core plug samples in the first $\sim 1,450 \mathrm{~m}$ of the composite stratigraphic section was done using standard paleomagnetic field equipment and procedures, with both magnetic and sun compasses (Table S1). Most of the collected samples are mudstones, siltstones, and sandstones with preference for the finest grained layers whenever possible. In addition, a portion of samples was acquired in the siderite-rich carbonate layers of the Yaw Formation. The paleomagnetic results of the Yaw Formation are already published in preceding research for calculating a mean direction (Westerweel et al., 2019) and are herein interpreted for magnetostratigraphy.

On a $2 \mathrm{G}$ cryogenic magnetometer hosted in a magnetically shielded room at Geosciences Rennes, stepwise demagnetization was conducted on these samples in order to isolate their characteristic remanent magnetizations (ChRMs) from their total natural remanent magnetizations (NRMs). Both thermal demagnetization, with increments of $20^{\circ} \mathrm{C}$ to $50^{\circ} \mathrm{C}$ up to $680^{\circ} \mathrm{C}$, and 3-axis alternating field (AF) demagnetization, with increments of 2.5-10 up to $120 \mathrm{mT}$, were used for this. During AF demagnetization, gyro remanent magnetizations (GRMs) were canceled by measuring the magnetization after each axis of AF demagnetization (Roperch \& Taylor, 1986). The demagnetization of individual samples was plotted on orthogonal demagnetization plots (Zijderveld, 1967), and their ChRM directions were isolated using principal component analysis (Kirschvink, 1980) or in some cases a Fisher mean on the demagnetization results (Fisher, 1953). Subsequently, these ChRM directions were corrected for the tilt of the sedimentary bedding and then grouped based on polarity (normal or reverse) and data quality (Categories 1 or 2). Samples are denoted as Category 1 when both the polarity and ChRM direction are well constrained, while demagnetization is less stable in Category 2 samples, but the polarity can still be inferred. Afterwards, the reversal angle of each sample, defined as the angular distance between the observed direction in an individual sample and the mean paleomagnetic direction in normal polarity, was plotted versus sampling level for constructing the magnetostratigraphic log. Subsequently, antipodal normal (black) and reverse (white) polarity magnetozones could be distinguished by sequences of samples exhibiting the same polarity. Finally, these magnetozones could be compared with the latest Geomagnetic Polarity Timescale (GTS16) (Ogg et al., 2016).

\subsection{Zircon U-Pb Dating}

To constrain the age and sedimentary provenance of the Chindwin Basin, one sandstone from the top of the Letkat Formation was sampled for zircon U-Pb dating during this study (17letkat07). Detailed analytical protocols and information about the data reduction schemes are provided in Text S1 and in Licht et al. (2020). Briefly, zircon crystals were extracted by traditional methods of heavy mineral separation. U-Pb ages were generated using laser-ablation inductively coupled-plasma mass-spectrometry (LA-ICP-MS), using an iCAP RQ Quadrupole ICP-MS coupled to an Analyte G2 excimer laser at the University of Washington, using a spot diameter of 25 microns. Data reduction was first conducted with Iolite, using their U_Pb_Geochron4 Data Reduction Scheme to calculate U-Pb ages uncorrected for common lead (Paton et al., 2010). In addition, age uncertainties for all samples were calculated with Matlab using a modified version of the method of Matthews and Guest (2017) that takes into account the impact of 207Pb beam intensity on age uncertainties. The 10 secondary zircon reference materials during these sessions yielded offset around TIMS ages $<1 \%$ in most cases, $<2 \%$ otherwise.

Maximum depositional age for the detrital sample was calculated with multiple zircon ages using Tuffzirc (Ludwig, 2003). We also recalculated the crystallization age of a tuff layer and seven maximum depositional ages from the Yaw, Tonhe, and Letkat Formations in the same sedimentary section, already published in Licht et al. (2019) (Table S2) based on recalculated age uncertainties. To this, we added additional maximum depositional ages from Wang et al. (2014) and Cai et al. (2019) obtained elsewhere in the Yaw, Tonhe, and Letkat Formations (Table S1). The final age error calculated for each sample is the quadratic sum of the uncertainty of Tuffzirc age calculation and of the systematic uncertainty $\left(\sim 2.67 \%\right.$ for the ${ }^{238} \mathrm{U} /{ }^{206} \mathrm{~Pb}$ ratios; same value used for the samples of Wang et al., 2014 and Cai et al., 2019). Age distributions of all selected samples were compared on a multidimensional scaling (MDS) map, which is a visual way to assess the misfit between age distributions using the Kolmogorov-Smirnov (KS) statistic as the dissimilarity measure (Vermeesch, 2013). 


\subsection{Apatite U-Pb and Fission-Track Dating}

To further constrain the age, sedimentary sourcing and tectonic context of the Chindwin Basin, detrital apatites were extracted from the same eight sandstones for apatite U-Pb and AFT dating during this study (Table S3). Both types of ages were acquired simultaneously at the GeOHeLiS Analytical Platform (Geosciences Rennes), using an ESI NWR193UC Excimer laser coupled to a quadrupole Agilent 7700x ICP-MS. Detailed analytical conditions can be found in Text S1. A total of 120 grains were analyzed whenever possible.

Data reduction for $\mathrm{U}-\mathrm{Pb}$ ages was conducted with Iolite, using the VisualAgeUcomPbine Data Reduction Scheme of Chew et al. (2014) to calculate U-Pb ages corrected for common lead. Single grain ages and subsequent population mean ages were obtained following two different methods. Single grain ages were determined following the iterative approach for 207Pb correction of Chew et al. (2011), using a terrestrial $\mathrm{Pb}$ evolution model for the determination of common lead isotopic composition (Stacey \& Kramers, 1975). Population ages were calculated independently of single grain age calculation, using data uncorrected for common lead. Age populations were first defined by identifying linear arrays of data in Tera-Wasserburg (TW) plots using IsoplotR (Vermeesch, 2018). Per age population, ${ }^{207} \mathrm{~Pb} /{ }^{206} \mathrm{~Pb}$ ratio of each array was either anchored at a value given by the single stage $\mathrm{Pb}$ evolution model of Stacey and Kramers (1975) or unanchored. Anchored and unanchored ages are coherent for all populations. The final age error is the quadratic sum of the uncertainty of IsoplotR age calculation and of the systematic uncertainty (using the same values as for zircon $\mathrm{U}-\mathrm{Pb}$ ages, i.e., $\sim 2.67 \%$ for the ${ }^{238} \mathrm{U} /{ }^{206} \mathrm{~Pb}$ ratios).

AFT data were obtained on the same spot as the U-Pb measurements using the protocol of Cogné et al. (2020). Spontaneous tracks were acquired by acid etching with $5.5 \mathrm{M} \mathrm{HNO}_{3}$ at $21^{\circ} \mathrm{C}$ for $20 \mathrm{~s}$. Grain mounting and etching procedure is analogous to the protocol described by Donelick et al. (2005). Fission-track counting was done using a Zeiss AxioImager Z1m microscope equipped with an Autoscan automated stage system. Data reduction was conducted with Iolite with a modified version of the Trace_Elements DRS (Woodhead et al., 2007) and an in-house spreadsheet. The different populations were then untangled using U-Pb data. AFT data were plotted in a radial plot to get the AFT age of the population, using IsoplotR (Vermeesch, 2018). All populations identified show a low degree of AFT single grain age dispersion.

\section{Results}

\subsection{Sedimentology}

Our 2010 m composite sedimentary log of the Yaw, Tonhe, and Letkat Formations is displayed in Figure 3. Deposits and associated lithofacies of these formations have already been extensively described and illustrated in Licht et al. (2019) (section 2.4.2), only our new sedimentological observations are presented here. In particular, previous studies near Kalewa have grouped both the Tonhe and Letkat Formations into a larger Letkat Formation (Licht et al., 2019; United Nations, 1978; Zat \& Aung, 2018; Zhang et al., 2019). However, our observations show that the Yaw, Tonhe, and Letkat Formations all have distinctive features and are separated by abrupt changes in sedimentary facies. The contact between the Yaw Formation and Tonhe Formation is sharp, marked by the occurrence of two consecutive sandstone bodies with thick ( $>2 \mathrm{~m}$ ) basal lags including blocks of reworked sediment, altered siderite, and lignified fossil trunks. The shallow marine to continental sedimentary facies of the estuarian Yaw Formation are replaced by solely continental fluvial deposits in the Tonhe Formation and the subsequent Letkat Formation. The Tonhe Formation is $\sim 250 \mathrm{~m}$ thick and is particularly coarse, with gravel beds made of rounded quartz being common forming stacked beds of trough cross-bedding. Gravel and sand beds are organized in 5- to 15-m-thick packages, each overlain by a 1- to 4-m-thick paleosol profile resembling modern ultisols (Figures 4a and 4b). Paleosols are red to brown, with gray, green, red, orange, and purple mottles, occasionally following root traces; parent sediment is highly mixed, and peds are blocky; they sometimes display a high density of red adhesive meniscate burrows, similar to ichnogenus Naktodemasis sp. (Figure 4c; Smith et al., 2008). Carbonated pedogenic nodules are particularly small and have only been found in two beds at the top of the unit ( $<2 \mathrm{~mm}$ in diameter). Sparse silicified and lignified fossil trunks can be found within gravel beds (Figure $4 \mathrm{~d}$ ).

The contact between the Tonhe and Letkat Formations is marked by the abrupt disappearance of gravel beds. Gravels are sporadically present in the Letkat Formation but only reappear much later, $\sim 500 \mathrm{~m}$ 
higher in the section, in isolated channel lags or as small lenses in bigger sand beds together with mud breccias. The sandstone beds of the Letkat Formation are stacked sometimes over more than $60 \mathrm{~m}$ of thickness without any change in facies or grain size (Figure 4e). Sands are rich in plant debris (Figure 4f) and include rare rounded vertebrate bones and lignified wood pieces. Paleosols occur at a much lower frequency than in the Tonhe Formation, every 50 to $200 \mathrm{~m}$ in the section, isolated or in packages of 2-4 profiles. These paleosols are 0.5 to $1.5 \mathrm{~m}$ thick and resemble modern vertisols with brown to gray with purple, red, and green mottles; parent sediment is finer (silt to very fine sand), highly mixed, and peds are blocky or rounded. They include $0.5-$ to $1.5-\mathrm{cm}$-thick carbonated pedogenic nodules. The transition to the overlying Natma Formation is marked by a sudden decrease in grain size, with pedogenised brown to red clay and silt becoming the dominant facies; sandstone bodies in the Natma Formation are commonly thinner (1-5 m thick), embedded into finer-grained material, and display inclined heterolithic stratifications.

\subsection{Rock Magnetism}

\subsubsection{Magnetic Properties}

We measured the volume-corrected bulk magnetic susceptibility (SI) of our core plug samples before demagnetization, as well as the 63 additional hand samples from the Letkat Formation (Table S1). The obtained values were plotted against the (magneto)stratigraphic results, showing that the Yaw, Tonhe, and Letkat Formations have distinct magnetic properties (Figures 5-7). Bulk magnetic susceptibilities of samples from the Yaw Formation are of low magnitude in general, averaging around $\sim 0.0002-0.0003$ SI. Exceptions to this are the siderite-rich rocks, which are easily recognized by much higher magnetic susceptibilities of around 0.0015-0.0025 SI. K-T, hysteresis, and IRM plots (Figure 5) confirm these results, showing that the magnetic properties of most rocks in the Yaw Formation, especially the finer-grained and siderite-rich rocks, are dominated by paramagnetic components with only a minor contribution of magnetite, which is the magnetic carrier based on stable demagnetizations above $400^{\circ} \mathrm{C}$ (Figure S2). Upon heating, the magnetic susceptibility increases at $\sim 370^{\circ} \mathrm{C}$ in many samples with paramagnetic characteristics, likely due to the transformation of iron sulfide minerals, such as pyrite, to magnetite. An even larger increase in magnetic susceptibility occurs in siderite-rich rocks above $400^{\circ} \mathrm{C}$.

Measured bulk magnetic susceptibilities from the Tonhe Formation, mostly from siltstones and sandstones, are distinct from those of the underlying Yaw Formation. In general, they are of an even lower magnitude than in the Yaw Formation, averaging around $\sim 4 * 10^{-5}$ to $1.5^{*} 10^{-4}$ SI. These low values suggest only a minor presence of magnetite. Nonetheless, IRM acquisition shows that magnetic remanence is still carried by magnetite, although several finer-grained, pedogenised sandstone samples exhibit high coercivity phases as well (Figure 5d).

The transition to the Letkat Formation is even more abrupt compared to the Yaw-Tonhe boundary with a sharp and significant increase in overall magnitudes of bulk magnetic susceptibility, averaging around 0.001-0.003 SI. K-T, magnetic hysteresis, and IRM acquisition experiments on the predominantly sandstone lithologies of the Letkat Formation show that magnetic properties and remanence in this formation are dominated by pseudo-single domain or multidomain magnetite, although IRM acquisition shows the occurrence of high coercivity phases related to hematite in several samples, especially in finer-grained sands where pedogenesis is observed (Figure $5 \mathrm{~d}$ ).

Before demagnetization (Figure S2), the AMS of all paleomagnetic samples was measured (Figure S3). In the Yaw, Tonhe, and Letkat Formations, the obtained magnetic fabric is mainly oblate with the minimum axis $K_{\min }$ of the AMS fabric oriented orthogonal to the bedding. In addition, the maximum axes $K_{\max }$ are oriented $\sim$ NNE-SSW, parallel to the fold axis of the stratigraphic section. These properties are typical for a sedimentary AMS fabric with ESE-WNW tectonic shortening. Only the siderite-rich rocks in the Yaw Formation depart from these trends, sometimes exhibiting an inverse AMS fabric which is often observed for this lithology (Rochette, 1988). The AMS in the Letkat Formation is on average much higher compared to the underlying formations, with a few coarse-grained sandstone samples having $P^{\prime}$ anisotropy values up to 1.6-1.8 (Figure 5b). This is probably related to an increase in magnetite content.

\subsubsection{Petrologic and Mineralogic Observations}

Optical microscope and SEM observations were made during this study to further investigate the inferred (magnetic) mineralogy from the measured magnetic properties. Observations from sandstones, mudstones, 

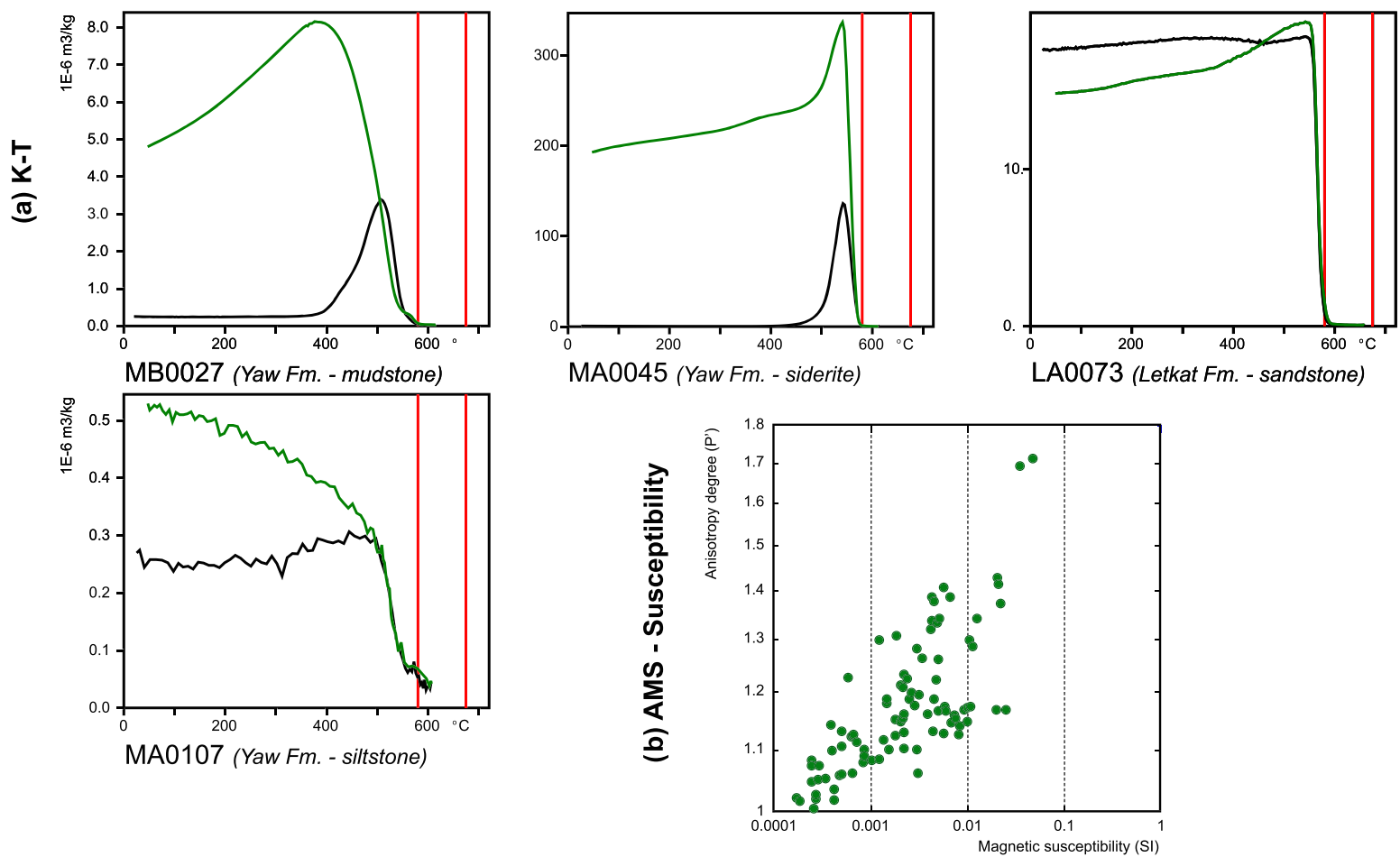

Letkat Fm
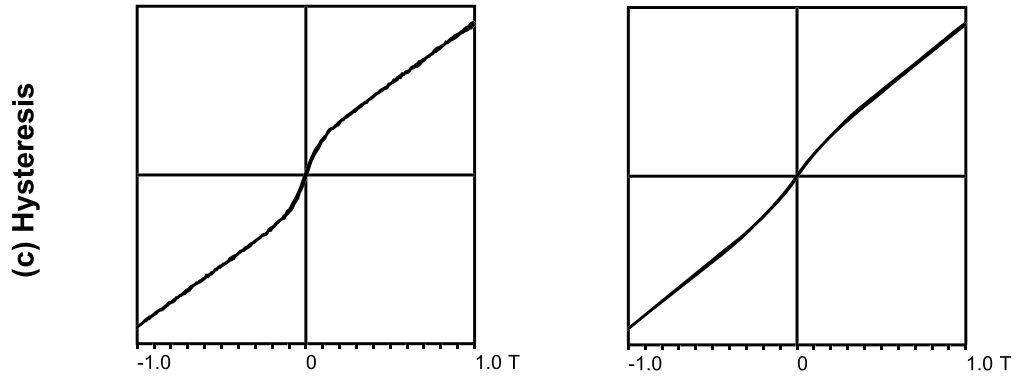

MB0064 (Yaw Fm. - mudstone)

MA0045 (Yaw Fm. - siderite)
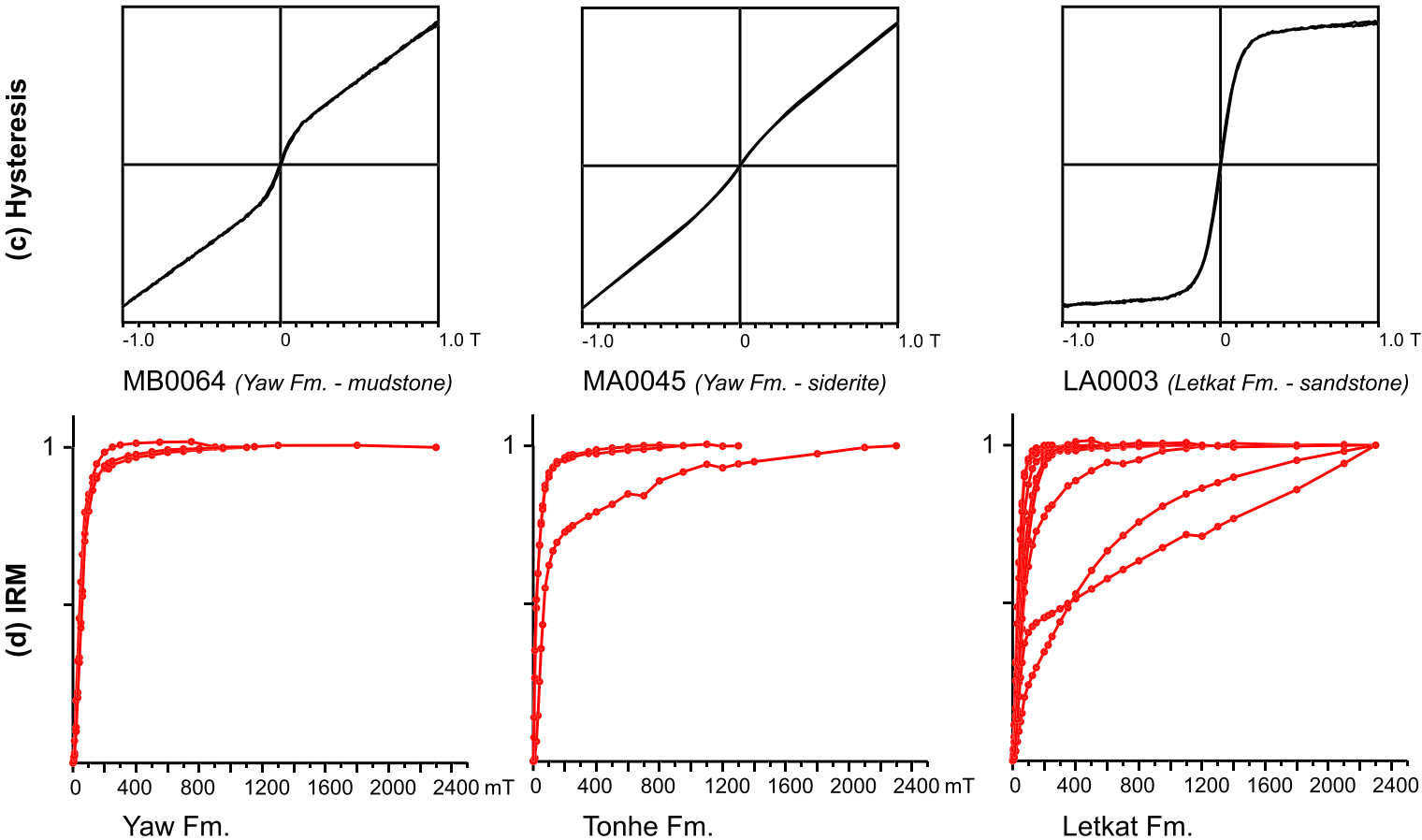

LA0003 (Letkat Fm. - sandstone)

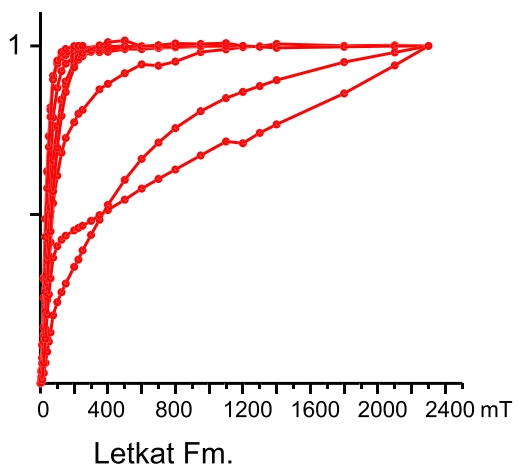

Figure 5. Rock magnetic experiments showing differences in magnetic properties between the Yaw, Tonhe, and Letkat Formations. (a) Representative bulk magnetic susceptibility $\left(10-6 \mathrm{~m}^{3} / \mathrm{kg}\right)$ versus temperature $\left({ }^{\circ} \mathrm{C}\right)$ plots $(K-T$ plots $)$ up to a maximum of $590^{\circ} \mathrm{C}$, (b) plot of degree of anisotropy $\left(P^{\prime}\right)$ versus bulk magnetic susceptibility (SI), (c) hysteresis loops, and (d) plots of isothermal remanent magnetization (IRM) acquisition.

and siderites in the Yaw Formation largely confirm the inferred (magnetic) mineralogy. Yaw Formation lithologies typically contain large concentrations of siderite and organic material (Figures 6a-6c), and an abundance of framboidal pyrite grains is often observed in and around these organic-rich parts (Figure 6a). Furthermore, the fine- to coarse-grained sandstone parts consist of subangular and poorly sorted clasts, 

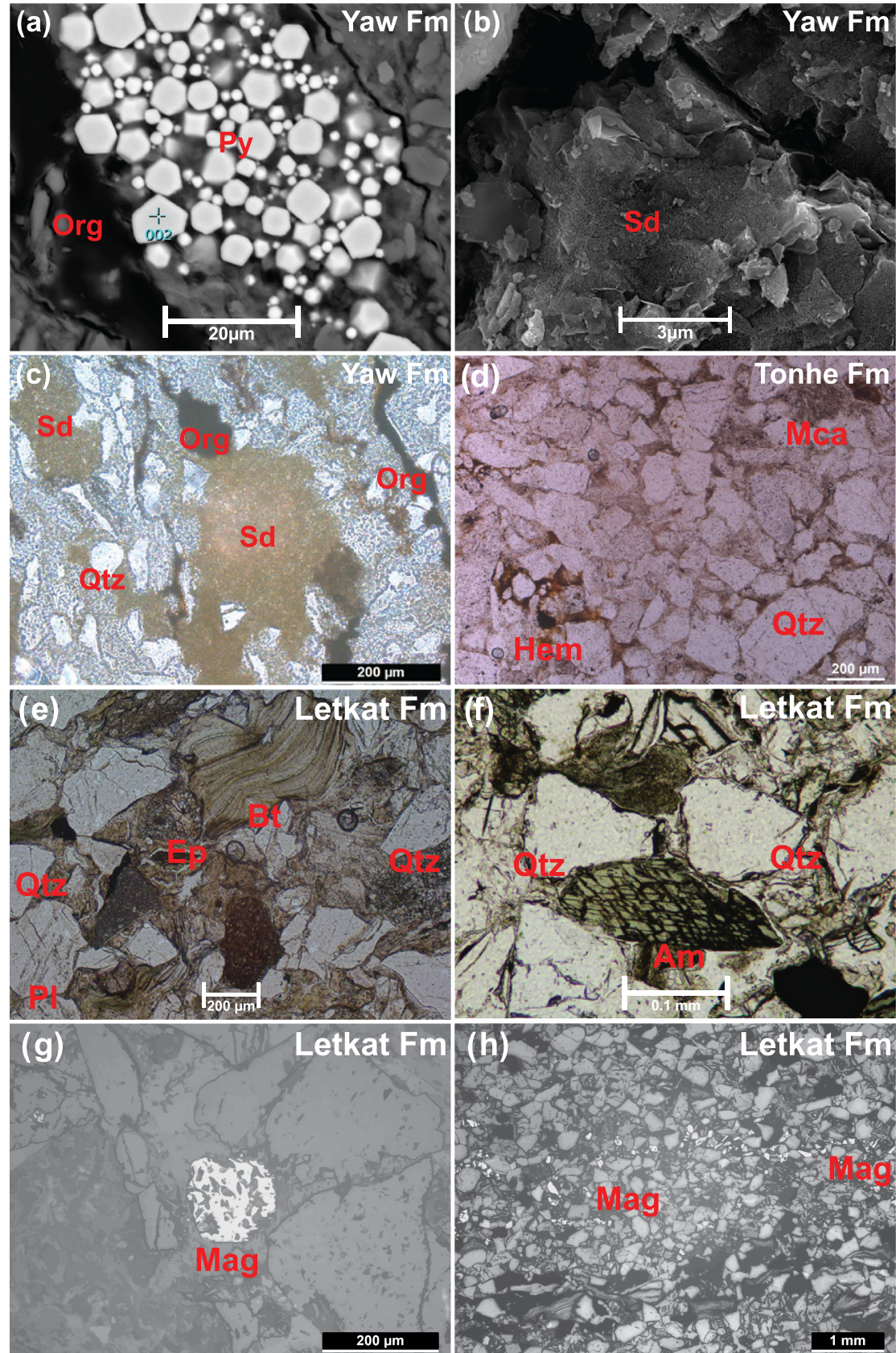

Figure 6. Representative microscope images showing differences in mineralogy between the (a-c) Yaw, (d) Tonhe, and $(\mathrm{e}-\mathrm{h})$ Letkat Formations. Sample name and scale are indicated per image. Mineral abbreviations (red): $\mathrm{Am}=$ amphibole, $\mathrm{Bt}=$ biotite, $\mathrm{Ep}=$ epidote, $\mathrm{Hem}=$ hematite, $\mathrm{Mag}=$ magnetite, $\mathrm{Mca}=$ mica, $\mathrm{Org}=$ organic material, $\mathrm{Pl}=$ plagioclase, $\mathrm{Py}=$ pyrite, $\mathrm{Qtz}=$ quartz, $\mathrm{Sd}=$ siderite .

mostly (polycrystalline) quartz, and a contribution of feldspars and micas, as well as several zircons, apatites, and volcanic rock fragments. Quartz minerals often look recrystallized, exhibiting dissolution features at their edges (Figure 6c). These observations corroborate the strong paramagnetic behavior of the Yaw Formation lithologies with only minor evidence for magnetite.

Like the Yaw Formation, sandstones from the overlying Tonhe Formation are comprised almost exclusively of (polycrystalline) quartz minerals (Figure 6d). They are usually subrounded and poorly sorted. The biggest grains are cemented by a finer-grained matrix, consisting of quartz or phyllosilicates. Especially in this finer-grained matrix, oxidation features are present as well. However, in contrast to the Yaw Formation, 
$\begin{array}{ll}\text { (a) Geochronology } & \text { (b) Magnetic susceptibility }\end{array}$

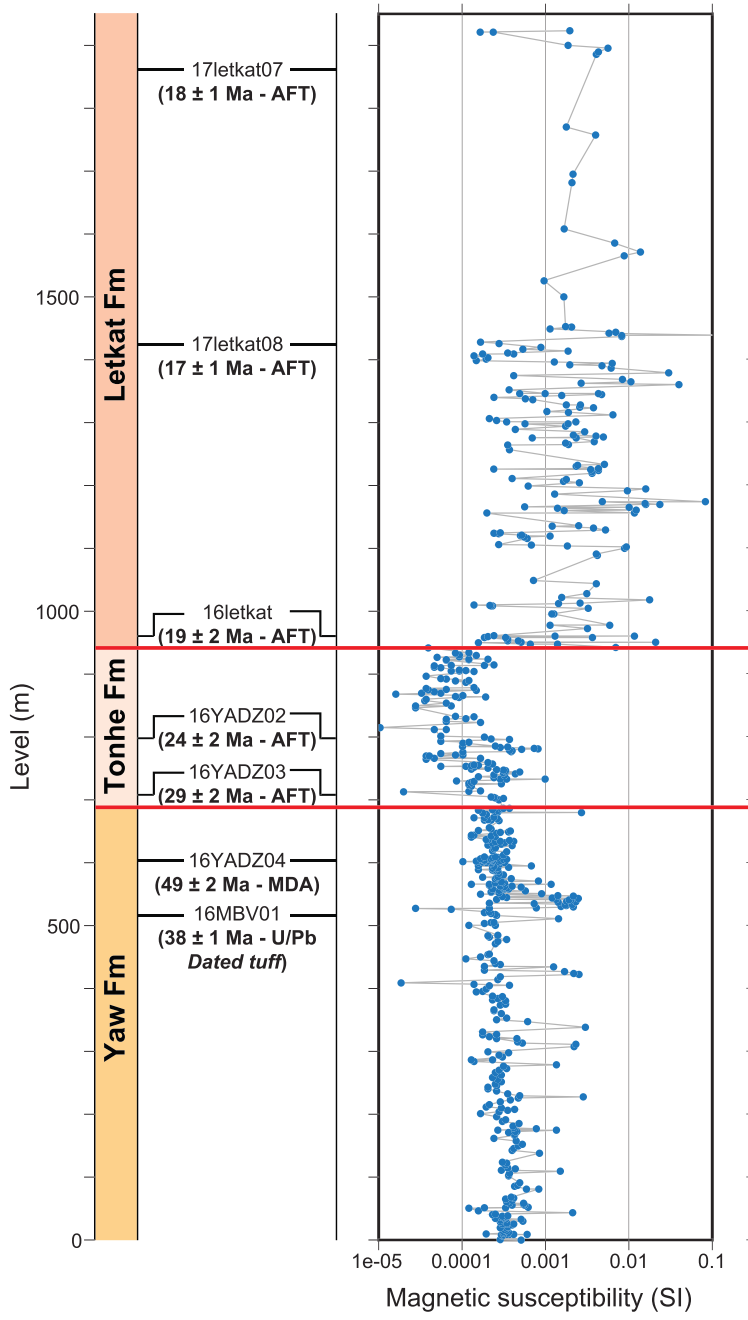

(c) Magnetostratigraphy

$\begin{array}{lll}\text { (d) GTS16 } & \text { (e) Palynology }\end{array}$ Chindwin

Figure 7. Overview of stratigraphy, magnetic properties and magnetostratigraphy of this study: (a) formation depths and geochronology results (Table S1); (b) bulk magnetic susceptibility (SI) log; (c) magnetostratigraphic results (left) and interpretation (right); (d) comparison with geomagnetic polarity timescale (GTS16) (Ogg et al., 2016); (e) palynological age constraints from the Chindwin Basin: (1) = Meyeripollis naharkotensis, Cicatricosisporites dorogensis, and Proxapertites operculatus (Huang et al., 2020); (2) = Florschuetzia semilobata (Lwin et al., 2017). Formation colors are identical to Figure 1b. Red lines highlight the two unconformities constrained by this study of latest Eocene-middle Oligocene and late Oligocene-early Miocene age.

organic and sideritic material is lacking in the Tonhe Formation. Optical microscope observations show that there is a near absence of opaque minerals such as magnetite. This is all in agreement with the low magnetic susceptibilities, induced by only a minor presence of magnetite in the Tonhe Formation.

Sandstones from the Letkat Formation are composed of much coarser, less sorted, and more angular clasts compared to the underlying formations (Figures 6e-6h). In addition to the minerals common in the underlying formations, the sedimentary composition of the Letkat Formation includes a significant amount of high-grade metamorphic and ultramafic minerals, such as quartz, (perthitic) feldspar, biotite, muscovite, epidote, and amphibole (Figures 6e and 6f). Fragments of high-grade metamorphic rocks such as schist and quartzite can be identified as well. In contrast to Yaw sandstones, little to no organic and siderite material is present. Large grains and concentrations of (occasionally oxidized) magnetite, sometimes alongside titanite, rutile, ilmenite, and titanomagnetite, are easily observed in coarse-grained sandstones, often occurring as thin bedded layers (Figures $6 \mathrm{~g}$ and $6 \mathrm{~h}$ ). From this, it can be inferred that the highly degree of AMS in the Letkat rocks are related to a highly anisotropic distribution of magnetite due to concentration of heavy minerals by gravity separation during sedimentary transport instead of paleocurrents (Figure 5b), illustrating the difficulty in using AMS for reliable paleocurrent determinations. Our mineralogic observations are in 
good agreement with the obtained magnetic properties of Letkat rocks, confirming that they are dominated by large grains of magnetite.

\subsection{Magnetostratigraphy}

In total, 298 demagnetized samples were sorted according to depth and data quality and subsequently used to construct a magnetostratigraphic section (Figure 7 and Table S1). Rocks from the late Eocene Yaw Formation $(0-680 \mathrm{~m})$ often yield stable demagnetizations with ChRMs that were mostly determined in the temperature interval $\sim 220^{\circ} \mathrm{C}$ to $460^{\circ} \mathrm{C}$, with best-fitted lines anchored to the origin. The most stable samples are from fine-grained mudstone rocks and a few siderite-rich carbonate layers, whose ChRM directions are in good correspondence with each other. Stable samples with coherent polarities and ChRM directions were denoted as Category 1 in Figure 7, while samples with distinguishable polarities but less constrained ChRM directions were denoted as Category 2. The remaining samples, often coarse-grained siltstones and sandstones with persistent overprint of the magnetic signal in the present-day field, were not used for magnetostratigraphy. Despite these occurrences, the Yaw Formation exhibits well-defined antipodal normal and reverse magnetozones. Rocks of both polarities exhibit similar magnetic behavior during demagnetization, suggesting a detrital or early diagenetic primary origin for the ChRMs. Hence, the ChRMs were corrected for the general tilt of our homoclinal sedimentary section (Azimuth/Dip $=\sim 010 / 40 \mathrm{E}$ ). This resulted in seven distinct magnetozones for the Yaw Formation, which were labeled Y.n1-Y.n4 (normal) and Y.r1-Y.r3 (reverse).

The majority of samples in the overlying Tonhe Formation and especially in the Letkat Formation are characterized by significant overprint of the magnetic signal (often by the present-day field), likely related to the presence of multidomain magnetite in the coarse sandstones comprising the majority of lithologies in both formations (section 4.2 and Figures 5 and 6). AF demagnetization was completely ineffective in removing these overprints. Thermal demagnetization yielded a few stable samples, with roughly similar demagnetizations as those from the Yaw Formation (Figures 7 and S2). The resulting stratigraphic resolution was insufficient to build a magnetostratigraphic correlation for the Tonhe and Letkat Formations, but fortunately, their ages could be reliably determined using other geochronological constraints (section 5.1).

\subsection{Zircon U-Pb Dating}

Youngest $\mathrm{U}-\mathrm{Pb}$ age populations of detrital zircons from the Yaw, Tonhe, and Letkat Formation are displayed in Table S1, alongside the recalculated volcanic tuff age in the Yaw Formation (Licht et al., 2019), which now yields an age of $37.8 \pm 1.1 \mathrm{Ma}(2 \sigma ; n=14$ zircons) (Licht et al., 2019). Kernel density estimates (KDE) and age histograms of $\mathrm{U}-\mathrm{Pb}$ age distributions of new sandstone sample 17letkat07 as well as published sandstones from Licht et al. (2019) of the Yaw, Tonhe, and Letkat Formations are shown in Figure 8. These samples, as well as additional samples from the Chindwin Basin (Cai et al., 2019; Wang et al., 2014; Zhang et al., 2019) and modern river sediments in Myanmar (Garzanti et al., 2016) are compared on a MDS map to show changes in provenance (Figure 9).

Yaw Formation and Tonhe Formation sandstones from the Chindwin Basin are dominated by Late Cretaceous ( 120-90 Ma), Paleogene ( 60-40 Ma), and pre-Cretaceous zircon populations (Figure 8 and Table S2). Samples from the Yaw and Tonhe Formations also yield a significant proportion of older zircons, with two notable peaks at 500 and 1,200 Ma. Sandstones from the Letkat Formation appear statistically different from other sandstones on the MDS plot (Figure 9), with a prominent age population of Paleogene grains but a smaller population of pre-Cretaceous grains compared to Yaw and Tonhe samples.

\subsection{Apatite Dating}

$\mathrm{KDE}$ and age histograms of apatite $\mathrm{U}-\mathrm{Pb}$ age distributions of sandstones of the Yaw, Tonhe, and Letkat Formations are shown in Figure 8. Determinations of U-Pb age population averages and uncertainties on TW diagrams are displayed on Figure S4. AFT radial plots are displayed on Figure 10. In all cases, apatites yielding the youngest $\mathrm{U}-\mathrm{Pb}$ ages also yielded the youngest AFT ages (Table $\mathrm{S} 1$ ).

Apatite $\mathrm{U}-\mathrm{Pb}$ and AFT ages of sandstones from the Yaw Formation are all older than the youngest zircon ages and older than the age of the dated tuff. Given the thickness of the sedimentary sequence, post-depositional annealing of tracks cannot be excluded for these two samples. However, the youngest population in 16YADZ01 shows similar apatite $\mathrm{U}-\mathrm{Pb}$ and AFT ages. Therefore, it is likely that annealing 
Zircon U-Pb ages

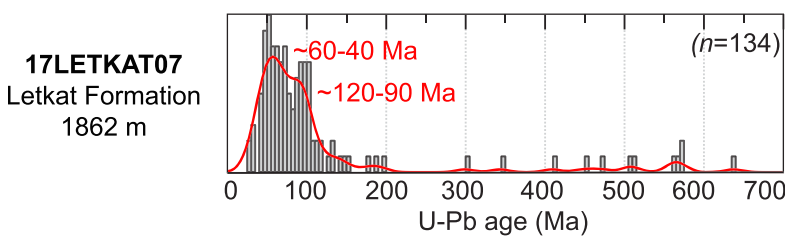

This study

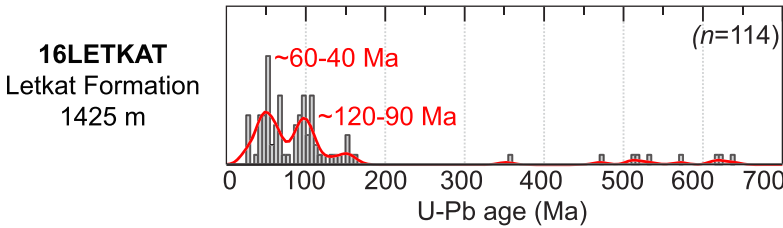

Licht et al. (2019)

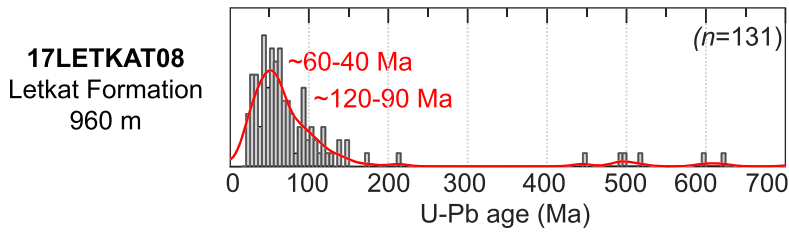

Licht et al. (2019)

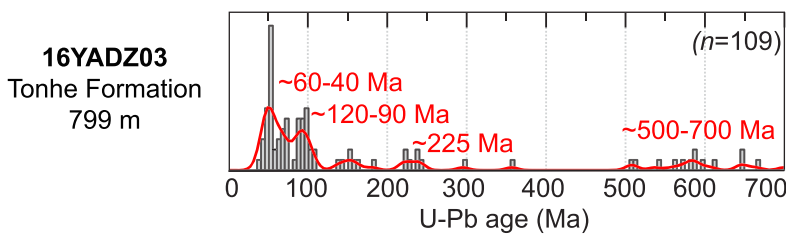

Licht et al. (2019)

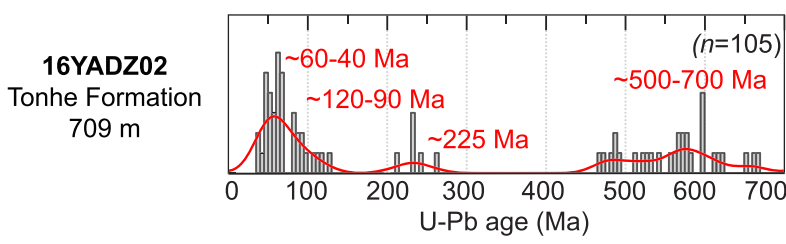

Licht et al. (2019)

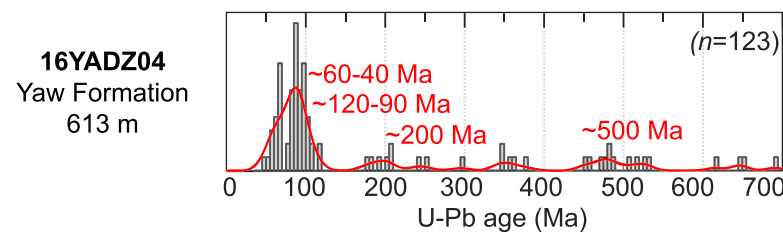

Licht et al. (2019)

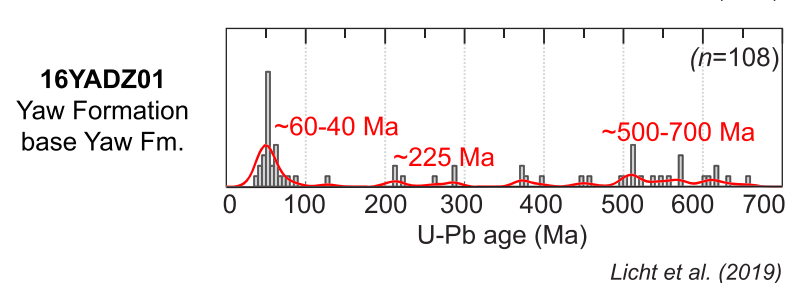

Licht et al. (2019)
Apatite U-Pb ages
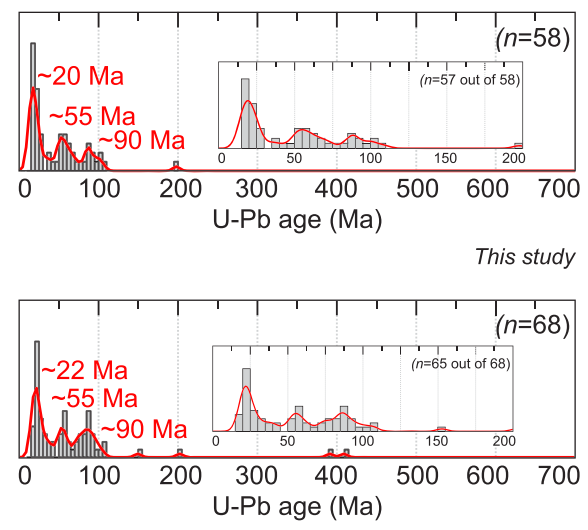

This study

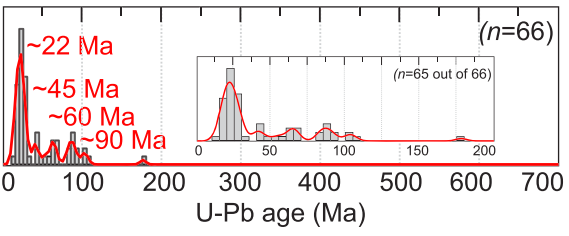

This study

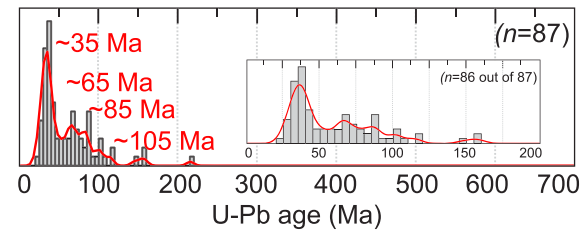

This study

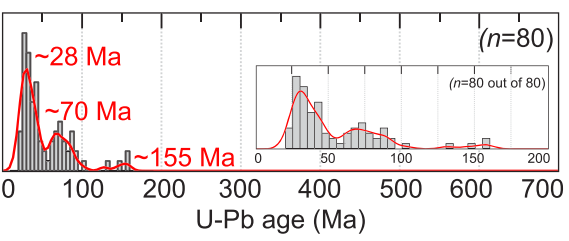

This study

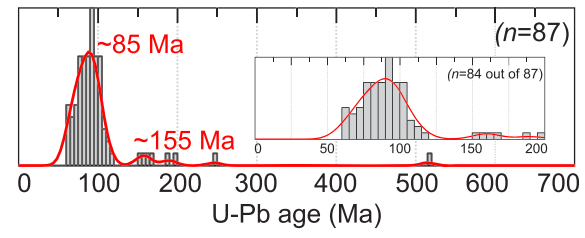

This study

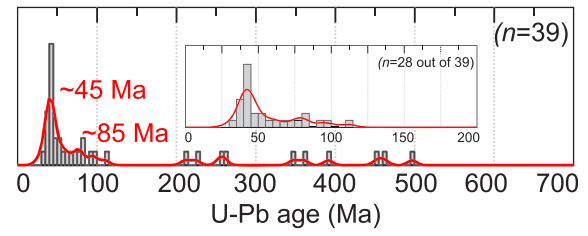

This study

Figure 8. Kernel density estimators (KDE) and histograms (5 Myr bins) for individual sandstone samples of this study for zircon U-Pb ages from this study (17letkat07) and Licht et al. (2019), as well as and apatite U-Pb ages from this study. The kernel density bandwidth of each plot was determined with the plug-in bandwidth selection method of Botev et al. (2010). Apatite U- $\mathrm{Pb}$ ages are 207-corrected ages for common lead; we excluded apatite ages with high age uncertainties (2s $>50 \%$ ) usually reflecting low $\mathrm{U}$ content. 


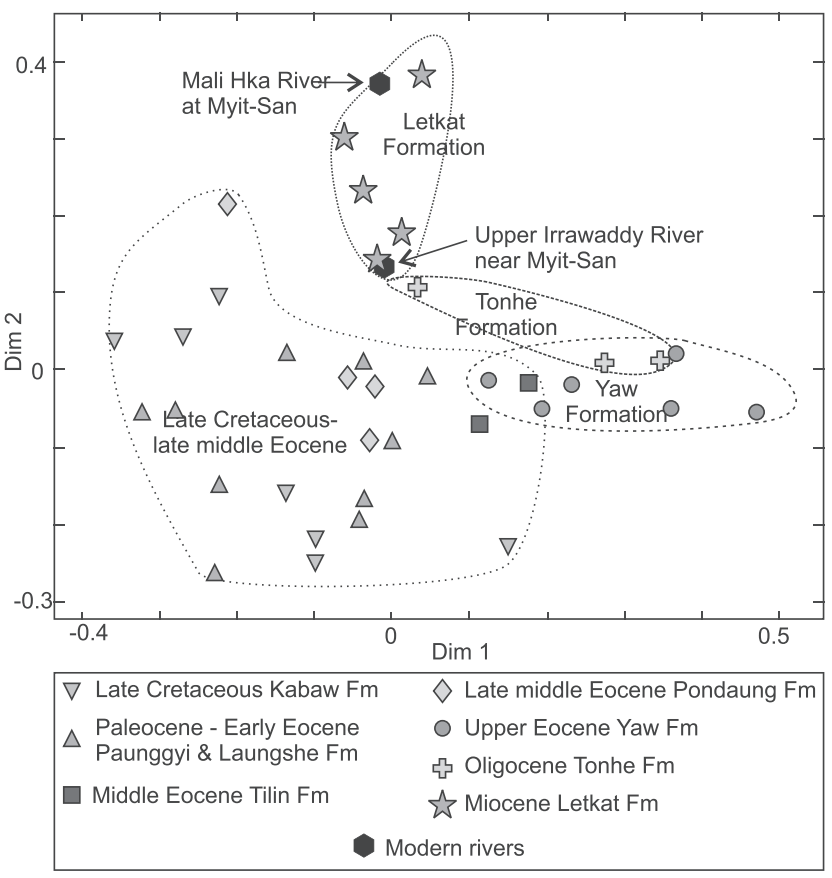

Figure 9. Multidimensional scaling map showing the dissimilarities between individual samples of this study and previously published samples (Cai et al., 2019; Garzanti et al., 2016; Licht et al., 2019;

Wang et al., 2014; Zhang et al., 2019). Axes are in dimensionless "KeS units" $(-1<\mathrm{KS}<1)$ of dissimilarity between samples. Final "stress" value is 0.11 , indicating a "fair" fit (Vermeesch, 2013). Ranges of variation for different units are highlighted by dashed lines. is minor if present. Most apatite $\mathrm{U}-\mathrm{Pb}$ and AFT ages for sandstones of the Tonhe Formation are younger than the $\sim 35-30$ Ma zircon ages of the same sandstones, with the youngest population at $\sim 30-25$ Ma. These ages remain in the proposed age range for the deposition of the Tonhe Formation based on pollen assemblages (upper Oligocene; Lwin et al., 2017; R. Morley, pers. com.). Similarly, apatite U-Pb and AFT ages of sandstones from the Letkat Formation are commonly younger than their youngest zircon $\mathrm{U}-\mathrm{Pb}$ age population ( 27-17 Ma) with the youngest population showing a U-Pb age of $\sim 22-20 \mathrm{Ma}$ and an AFT age of $\sim 18 \mathrm{Ma}$. They are in the range of what has been proposed for the deposition age of the Lektat Formation: older than 14-11 Ma based on biostratigraphic data in the Mingin Gravels above and older than one zircon $\mathrm{U}-\mathrm{Pb}$ age dated $16.8 \pm 1.3 \mathrm{Ma}(2 \mathrm{~s})$ at the top of the unit by Wang et al. (2014). For both the Tonhe and Letkat Formations, the AFT and U-Pb youngest populations are close in time. We thus interpret these AFT ages to be detrital ages, exempt of resetting due to burial or annealing. Moreover, youngest AFT ages of Tonhe and Letkat sandstones never overlap with and are always much younger than zircon $\mathrm{U}-\mathrm{Pb}$ ages from the same samples. Therefore, we interpret AFT ages of these two formations to be non-volcanic, that is, to be a product of exhumation of older rocks, and to provide a limit on the maximum depositional ages of these sandstones.

\section{Interpretations}

\subsection{Age Model for the Chindwin Basin}

An overview of the different age constraints from magnetostratigraphy, $\mathrm{U}-\mathrm{Pb}$ and AFT dating, and palynology is presented in Figure 7. In the Yaw Formation, magnetozone Y.r1 was anchored to the GTS16 (Ogg et al., 2016) using the $37.8 \pm 1.1 \mathrm{Ma} \mathrm{U}-\mathrm{Pb}$ age from the dated tuff layer, correlating it with chron C17r.1r, which lies within the error range of the age of the tuff layer (Figure 7). From this, the other magnetozones of the Yaw Formation could be straightforwardly correlated with the GTS16, with the base of the section corresponding to chron C18n.1n and the top to chron C17n.1n, constraining the age of the section to $~ 38.4-37.2$ Ma. The very base of the Yaw Formation is located at $\sim 500$ m below our composite log; a sandstone near the base of the formation yielded a youngest zircon dated at $36.3 \pm 1.9$ Ma by Cai et al. (2019), which is within error range of our magnetostratigraphic age interval. The Pondaung Formation, just below the Yaw Formation, has been dated at 40-39 Ma using a combination of geochronology and biostratigraphy in the Minbu Basin (Jaeger et al., 1999; Licht, Cojan, et al., 2014; Licht et al., 2015; Zaw et al., 2014); this age is in agreement with the youngest zircon of another sample dated at $39.0 \pm 1.3 \mathrm{Ma}$ near the base of the Yaw Formation (Table S1). We thus assign an upper Bartonian age to the Yaw Formation by combining our constraints from magnetostratigraphy, the dated tuff and detrital zircon U-Pb dating. The magnetostratigraphic correlation confirms that the Yaw Formation was deposited under rapid sedimentation and subsidence rates $(\sim 0.6 \mathrm{~m} / \mathrm{ky})$, similar to previous estimations (Licht et al., 2019).

Above the Yaw Formation, our observations show sharp transitions in sedimentary facies, magnetic properties, mineralogy and maximum depositional ages at both the Yaw-Tonhe and Tonhe-Letkat boundaries (Figures 4-10 and Table S1). These are interpreted as two depositional unconformities occurring in the Chindwin Basin, separating the Tonhe Formation from the underlying Yaw Formation and overlying Letkat Formation. Unfortunately, these unconformable contacts, alongside the large effect of overprint of the magnetic signal in the Tonhe and Letkat lithologies, make it difficult to extend our magnetostratigraphic correlation from the Yaw Formation upward. Yet we can observe a distinct change in maximum depositional ages given by zircon $\mathrm{U}-\mathrm{Pb}$, apatite $\mathrm{U}-\mathrm{Pb}$, and AFT dating results between the three formations (Figures 3, 7, 8 , and 10 and Table S1). The youngest age at the base of the Tonhe Formation is $28.5 \pm 2.4 \mathrm{Ma}$ (AFT), while the youngest age higher in the section is $24.2 \pm 1.8 \mathrm{Ma}$ (AFT), both in agreement with the upper Oligocene age for the Tonhe Formation from palynology (Lwin et al., 2017; R. Morley, pers. com.). 

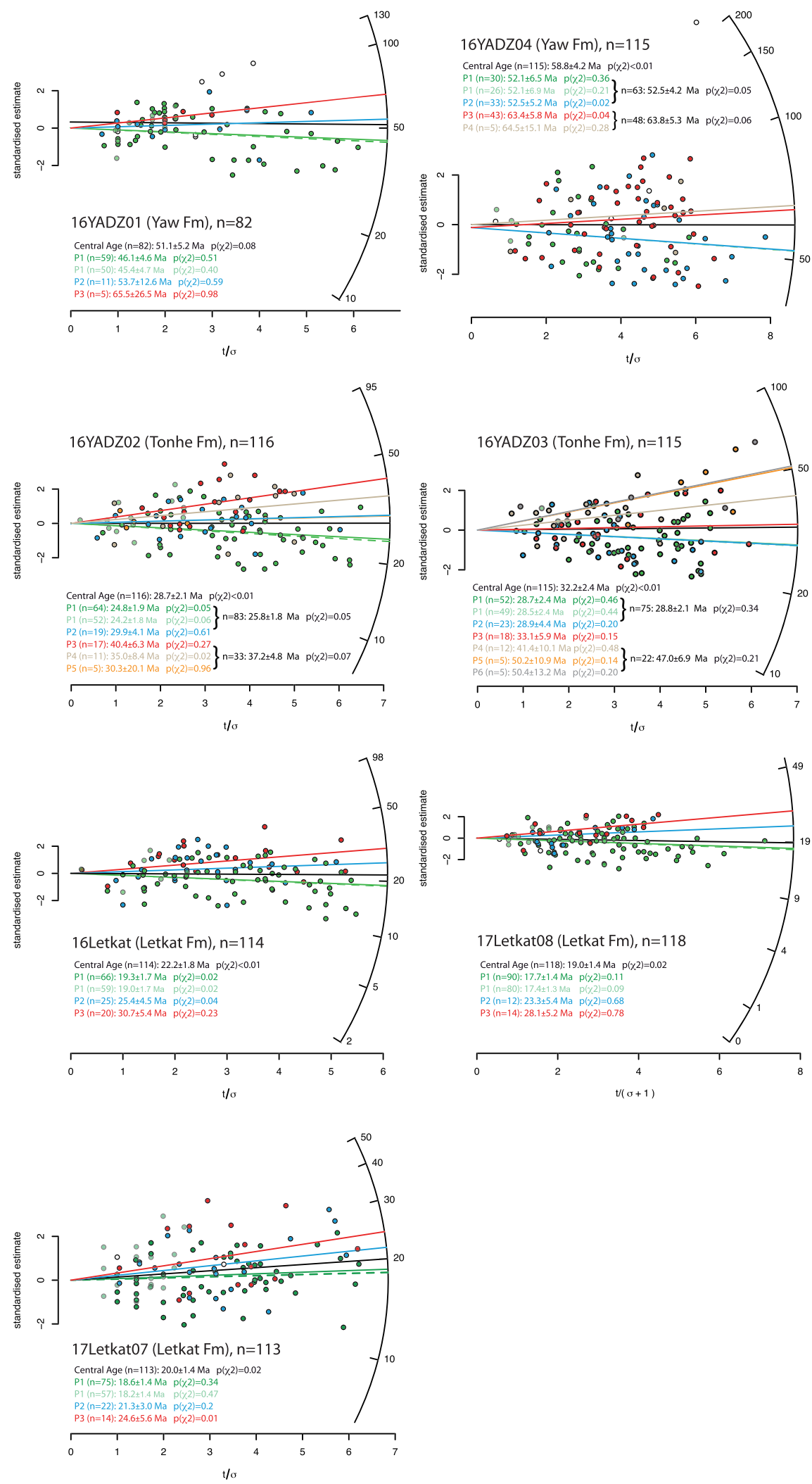

Figure 10. AFT radial plots for every sample analyzed in this study, showing the abrupt changes in youngest age population between the Yaw, Tonhe, and Letkat Formations. P1 to P6 indicate the different age populations (youngest to oldest) of each sample. 
The youngest AFT ages in the Letkat Formation are $19.0 \pm 1.7,18.2 \pm 1.4$, and $17.4 \pm 1.3 \mathrm{Ma}$; these ages are in agreement with a zircon dated at $16.8 \pm 1.3 \mathrm{Ma}$ at the top of the unit by Wang et al. (2014). The Letkat Formation cannot be younger than 14-11 Ma, based on the mammalian fauna age of the Mingin Gravels (Bender, 1983). This would thus indicate an upper lower Miocene (19-16 Ma) up to a lower middle Miocene age (up to 16-14 Ma) for the Letkat Formation. Two points suggest that the Letkat Formation does not extend up to the middle Miocene and is upper lower Miocene only: (1) the Natma and Shwethamin Formations form an additional 3-km-thick sequence of fluviatile deposits between the Letkat Formation and the base of the Mingin Gravels (United Nations, 1978); if the Letkat extended up to the upper lower Miocene, both units would require extremely high depositional and subsidence rates ( $>1.5 \mathrm{~m} / \mathrm{ky})$ to be deposited before 14-11 Ma; (2) the very short time lag between apatite youngest U-Pb and AFT age populations ( 2 Myr for the three samples) indicates high exhumation rates in the source areas and thus a short delay between the youngest AFT age and the actual depositional age of the unit. In summary, these constraints suggest significant depositional hiatuses before deposition of both the Tonhe and Letkat Formations. The first unconformity should be of latest Eocene to middle Oligocene age, while the second unconformity is likely of latest Oligocene to early Miocene age.

\subsection{Changes in Depositional Environment}

The combination and alternation of facies associations FA1 to FA4 in the Yaw Formation have previously been interpreted as reflecting a barrier-bound, quasi-closed estuary (Licht et al., 2019), and our interpretations here are in line with this previous work. Facies association FA1 with black mudstones and siderite beds reflects the subtidal, anoxic central basin depositional environment of the estuary (Anthony et al., 1996). FA2 reflects near-shore environments, tidal flat, and intertidal marsh or freshwater lakeshore deposits during periods of estuary closure (Licht et al., 2019). FA3 and FA4 are attributed to respectively bay-head deltaic river distributaries and coastal swamps (paleohistosols).

By contrast, the Tonhe and Letkat Formations are characterized by pure fluviatile deposition, suggesting complete overfilling of the Chindwin Basin. Thick, wide bodies made of trough cross-beddings lacking any clear inclined heterolithic stratification, and sometimes capped by finer-grained sets of pedogenised sands, suggest fluvial channel bodies typical of braided river systems (Leeder, 2009). Yet both fluviatile units display clear differences. The Tonhe Formation, with its coarse channel bodies (commonly gravelly) regularly alternating with thick ultisols, recalls braided channels in distal alluvial fans where channel avulsion is common and can create such regular packages (Leeder, 2009). The Letkat Formation is more monotonous and recalls long-term aggradation of a wide braided river and its floodplain; the replacement of ultisols by vertisols in the rare pedogenised fine-grained deposits suggest a shift to a more seasonal or drier climate at the time of deposition (Retallack, 2008).

Magnetic properties of these three geological units are also very different (Figures 5-7). The magnetic properties of the Yaw Formation samples do not evidence a significant contribution of magnetite to the magnetic susceptibility, as it is mainly controlled by paramagnetic minerals. Framboidal pyrites are observed in SEM, and magnetic susceptibility changes around $370^{\circ} \mathrm{C}$ suggest that pyrite transformed to magnetite upon heating. The main susceptibility peaks in the Yaw Formation (up to 0.002 SI) are however associated with siderite layers. Siderite also transforms to magnetite upon heating, and therefore, we cannot discard a siderite presence in most samples. In addition, SEM images show dissolution features in quartz grains (Figures 5 and 6). There are three potential causes to explain the lack of magnetite in the Yaw Formation sediments. The first one is a source poor in detrital magnetite. The second is the almost complete dissolution of iron-bearing minerals, such as magnetite, resulting in the formation of pyrite. This is a common process in anoxic depositional environments that are rich in organic material and sulfides (Roberts, 2015). Finally, chemical weathering in the upstream areas could have supplied enough iron to the basin for the formation of siderite-rich carbonate layers, possibly by dissimilatory iron reduction occurring in anoxic conditions (Tang et al., 2018). Chemical weathering of magnetite was potentially prolonged by sediment recycling. The magnetic properties of the Yaw Formation show that magnetite grains were not completely dissolved or otherwise were formed anew by early diagenesis, as they preserve a primary paleomagnetic record, evidenced by well-defined normal and reverse magnetozones with similar demagnetizations and no outliers (section 4.3 and Figure 7). 
The magnetic and mineralogical properties of the Tonhe Formation indicate a clear disappearance of pyrite and siderite (Figures 5 and 6), likely representing the shift from estuarian to a purely fluviatile environment lacking anoxic conditions. This is even more apparent in the braided river depositional environment of the overlying Letkat Formation, where magnetic properties are dominated by layers of large detrital magnetite grains and occasionally the occurrence of hematite in finer-grained, pedogenised overbank deposits (Figures 5-7). These changes in magnetic properties suggest a lack of anoxic conditions in contrast to the Yaw Formation, implying that chemical alteration of (magnetic) minerals during diagenesis and recycling played a much less significant role here (Roberts, 2015). This is further evidenced by the occurrence of larger and more angular sedimentary clasts, also comprising less stable minerals, such as serpentinized olivine and epidote (Figure 6).

Hence, the first unconformity between the Yaw Formation and Tonhe Formation shows an abrupt change from an anoxic estuarian to a purely fluvial depositional environment. This change in sedimentation conditions becomes even more pronounced in the braided river depositional environment of the Letkat Formation.

\subsection{Sedimentary Provenance \\ 5.3.1. Yaw Formation}

The bulk of detrital zircon and apatite U-Pb ages in the Yaw Formation, dated between 40 and $120 \mathrm{Ma}$ (Figure 8), correspond to the age span of volcanic activity in the proximal WPA (Zhang et al., 2017), suggesting this arc was a dominant source for sediments in the Chindwin Basin until at least the late Eocene, as already proposed in previous studies (Cai et al., 2019; Licht et al., 2019; Wang et al., 2014). However, the Wuntho Ranges (northern segment WPA) directly east of the Chindwin Basin has a more limited volcanic age range compared to the Yaw Formation, only yielding two age groups of $110-90$ and $42-36$ Ma (Barley \& Zaw, 2009; Gardiner et al., 2017; Licht et al., 2020; Lin et al., 2019). Furthermore, seismic interpretations show large parts of the WPA were buried by Eocene sediments within the CMB (Zhang et al., 2017). These observations suggest that the Yaw Formation, including its significant population of $~ 80-50$ Ma zircons (Figure 8 and Table S2), was not solely sourced by the WPA intersecting the CMB.

North of the BT, $>80-50$ Ma volcanic ages are present in the Sodon Batholith and in the Lohit Batholith, which are correlated with the WPA (Haproff et al., 2019; Lin et al., 2019) and could potentially be located in the reconstructed Greater Burma region as part of the Trans-Tethyan Arc (Figure 11a; Westerweel et al., 2019). For these reasons, we propose that the exhuming northernmost perpetuation of the WPA, forming a segment of the Trans-Tethyan Arc in the Greater Burma region, should have significantly contributed to the late Eocene sediment supply of central Myanmar alongside the Wuntho Ranges (Figure 11a). Similarly, pre-Cretaceous zircons in the Yaw Formation could have been supplied by exhuming basement rocks in the Greater Burma region to the north, because the Eocene Phokphur conglomerates in the northern IBR (Aitchison et al., 2019; Cai et al., 2019) and Eocene sediments in the northernmost Chindwin Basin (Arboit et al., 2020) have comparable pre-Cretaceous age peaks as the Yaw Formation suggesting similar sourcing (Figure 8). Yaw Formation sourcing from north of the BT could have occurred in the Burmese backarc where sparse paleocurrent measurements suggest southward directed drainage systems since the late Eocene (Figure 11a; Thein \& Maung, 2017). In any case, apatite U-Pb and AFT ages for the Yaw Formation are up to $30 \mathrm{Ma}$ older than the depositional age of the unit, suggesting that the Yaw Formation sources were just starting to get exhumed and that deeply buried rocks had not been exposed yet.

\subsubsection{Tonhe Formation}

The zircon $\mathrm{U}-\mathrm{Pb}$ age distributions from two sandstones of the Tonhe Formation are almost indistinguishable from those of the Yaw Formation (Figure 8). However, the third uppermost sandstone displays an age distribution that is statistically more similar to the Letkat sandstones. An increase in petrographic maturity is shown by the presence of large quartz gravels and illustrated in sandstone grain-counting results (Licht et al., 2019). Apatite U-Pb and AFT ages from the Tonhe Formation are also much younger compared to those in the Yaw Formation, as well as volcanic ages in the WPA (section 5.3.1). They are also much younger than zircon $\mathrm{U}-\mathrm{Pb}$ ages in the Tonhe Formation itself, with AFT ages being almost coeval to the proposed upper Oligocene age of deposition of the unit based on palynological evidence. Finally, the sedimentary facies of the Tonhe Formation, corresponding to an alluvial fan setting, suggest a relatively proximal source. 


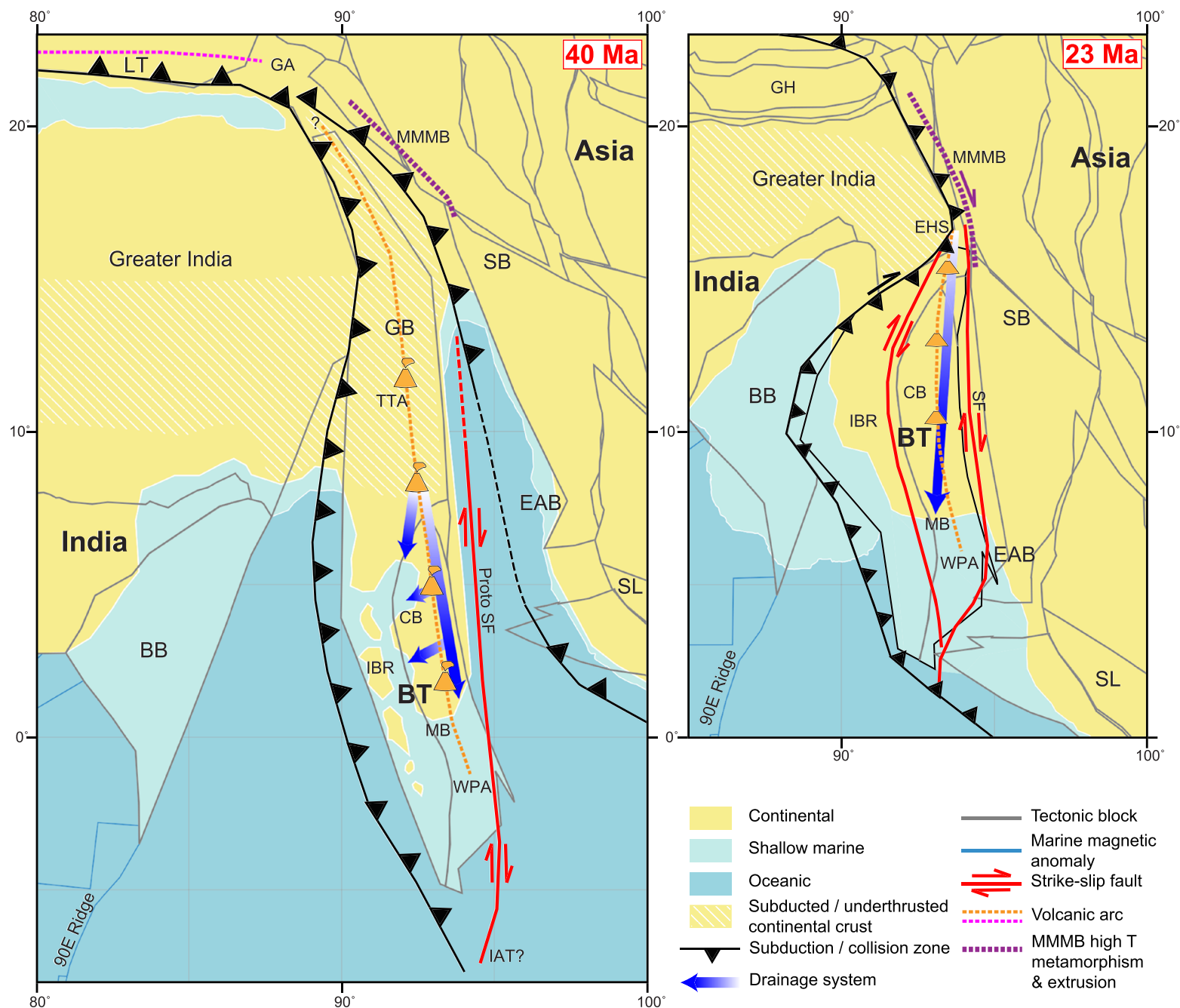

Figure 11. Paleogeography of the Burma Terrane at 40 (left) and $23 \mathrm{Ma}$ (right). Reconstructions were made with GPlates software (Müller et al., 2018), adapted from Westerweel et al. (2019) and modified using new tectonic constraints from Morley et al. (2020) as well as deforming plate margins (Müller et al., 2019) for the Burma Terrane, Greater India, and Bay of Bengal. Abbreviations: BB = Bay of Bengal, BT = Burma Terrane, CB = Chindwin Basin, EAB $=$ Eastern Andaman Basins, EHS = Eastern Himalayan Syntaxis, GA = Gangdese Arc, GB = Greater Burma, GH = Greater Himalayas, IAT = India-Australia Transform, $\mathrm{IBR}=$ Indo-Burman Ranges, $\mathrm{LT}=$ Lhasa Terrane, $\mathrm{MB}=$ Minbu Basin, MMMB $=$ Mogok-Mandalay-Mergui Belt, $\mathrm{SB}=\mathrm{Sibumasu}, \mathrm{SF}=\mathrm{Sagaing}$ Fault, $\mathrm{SL}=$ Sundaland, $\mathrm{TH}=$ Tethyan Himalayas, TTA $=$ Trans-Tethyan Arc, WPA = Wuntho-Popa Arc.

Together, this suggests the source remained the WPA and Greater Burma basement similar to the Yaw Formation. Prolonged exhumation in the Greater Burma region exposed more deeply buried rocks by this time, explaining the late Oligocene AFT ages that are close to the depositional age of the Tonhe Formation (Figure 10 and Table S1). Furthermore, the transitional provenance of the Tonhe Formation in between the Yaw and Letkat Formations and the observed increase in petrographic maturity could be explained by reworking of sedimentary rocks from the exhuming margins of the Chindwin Basin (Figure 9).

\subsubsection{Letkat Formation}

The zircon $\mathrm{U}-\mathrm{Pb}$ age distributions of the Letkat sandstones are significantly different from the underlying formations, characterized by (1) a decreased contribution of older, pre-Cretaceous zircons; (2) an increase of the Paleogene zircon age population; and (3) the presence of 27 to $17 \mathrm{Ma}$ zircon U-Pb ages, younger than the late Eocene magmatic event in the WPA (Mitchell et al., 2012; Wang et al., 2014; Zhang et al., 2017). This is accompanied by an increased occurrence of high-grade metamorphic grains (section 4.2 and Figure 6) and negative $\varepsilon H f(t)$ values (Wang et al., 2014; Zhang et al., 2019). Apatite U-Pb and AFT ages from Letkat sandstones provide the most interesting constraints on the age and source of these sediments, indicating rapid exhumation during the early Miocene, with only 2 Ma lag between these ages (Table S1). 
The presence of young Oligo-Miocene zircon ages indicates a contribution of the MMMB where these ages are present (Mitchell et al., 2012). The MMMB was located in the Eastern Himalayan Syntaxis north(-east) of the BT during deposition of the Letkat Formation (Figure 11b). Modern river sands from the Upper Irrawaddy River draining the MMMB in northern Myanmar and in the Eastern Himalayan Syntaxis are dominated by Paleogene grains (Garzanti et al., 2016), display young grains (30-17 Ma) and are notably poor in pre-Cretaceous zircons despite draining pre-Cretaceous metamorphics, further suggesting that this area could be an important source. The occurrence of ultramafic and high-grade metamorphic minerals, including the abundance of large detrital magnetite grains, in the Letkat deposits (section 4.2.2) and the appearance of Cenozoic zircons with negative $\varepsilon H f(t)$ values also support input from the MMMB (Gardiner et al., 2018). Finally, Ar-Ar ages on MMMB rocks in northern Myanmar and in the Eastern Himalayan Syntaxis indicate early Miocene exhumation, coeval to AFT ages of Letkat sandstones (Bertrand et al., 2001; Haproff et al., 2019). This is coeval with a major phase of shortening, thrusting and exhumation that has been documented for the Himalayan orogen during the early Miocene (e.g., Garzanti, 2019; Vannay et al., 2004). In the Eastern Himalayan Syntaxis directly north of the BT, this phase was even more rapid and intense with similar short lag times as recorded by our apatite U-Pb and AFT ages in the Letkat Formation (Table 1; Godin et al., 2006; Haproff et al., 2019; Kellett et al., 2013; Najman et al., 2019).

However, the MMMB largely lacks the $\sim 100$ Ma magmatic rocks that are prominent in the WPA. Because this age is still significant in Letkat sandstone age distributions, the WPA probably remained a substantial source in addition to the MMMB signal. This dual sourcing suggests the development of an integrated fluvial system in the CMB in the early Miocene, draining north to south. This is in agreement with SSW paleocurrent measurements in the Letkat Formation (Licht et al., 2019), coeval provenance data in the Minbu Basin showing a similar northern MMMB input (Zhang et al., 2019), and the sedimentary facies of the Letkat Formation that recall the set-up of a wide braided river and its floodplain.

\section{Implications for Regional Tectonic Evolution}

We explore here potential tectonic control on sedimentation in the Chindwin Basin that may explain the abrupt changes in sedimentary facies, magnetic properties, mineralogy, and provenance.

\subsection{Late Eocene-Middle Oligocene Unconformity}

The sedimentary facies, magnetostratigraphy, and provenance of the Yaw Formation record rapid subsidence $(\sim 0.6 \mathrm{~m} / \mathrm{ky})$ in the Chindwin Basin during the late Eocene. Moreover, there is evidence for coeval uplift in the WPA (Zhang et al., 2017) and incipient emergence of the IBR that sustained the quasi-closed estuarine system of the Chindwin Basin (Licht et al., 2019; Najman et al., 2020). The rapid subsidence has been related to pull-apart deformation of the Burmese forearc (Licht et al., 2019; Rangin, 2018). This is interpreted to relate to major dextral strike-slip displacement east of the BT, along a Proto-Sagaing Fault or IndiaAustralia Transform (Figure 11a; Morley et al., 2020; Westerweel et al., 2019).

The rapid subsidence is interrupted by the latest Eocene-middle Oligocene unconformity constrained by this study. It marks the onset of an uplift phase in the northern BT sometime in this period, evidenced by the occurrence of reworked sediments in the Tonhe Formation that were likely exhumed before (section 5.3.2 and Figures 3 and 7) and a late Eocene-Oligocene depositional hiatus observed within sedimentary sequences along the WPA (Zhang et al., 2017). The unconformity is also coeval with a proposed uplift event in the IBR (Licht et al., 2019; Morley et al., 2020; Najman et al., 2020), while continuous sedimentation prevailed in the Minbu Basin to the south (Bender, 1983; Licht et al., 2019).

This uplift phase in the northern BT could be explained by the collision of India and the BT along the northern segment of the IBR, recorded by Eocene emplacement of the Western Belt Ophiolite onto the Indian passive margin in the Naga Hills (Aitchison et al., 2019). However, the timing of this emplacement as suggested by Aitchison et al. (2019) is likely earlier in the Eocene, which is more in agreement with an initial early Paleogene (Paleocene-early Eocene) collision of India with the Trans-Tethyan Arc shown by plate reconstructions (Westerweel et al., 2019). According to these reconstructions, this first collision is followed by the collision of India, including the Greater Burma region, with the Asian margin during the late Eocene (Figure 11a; Haproff et al., 2020; Morley et al., 2020; Westerweel et al., 2019). This is supported by the coeval late Eocene onset of high temperature metamorphism along the MMMB (Searle et al., 2007, 2017, 2020) and 


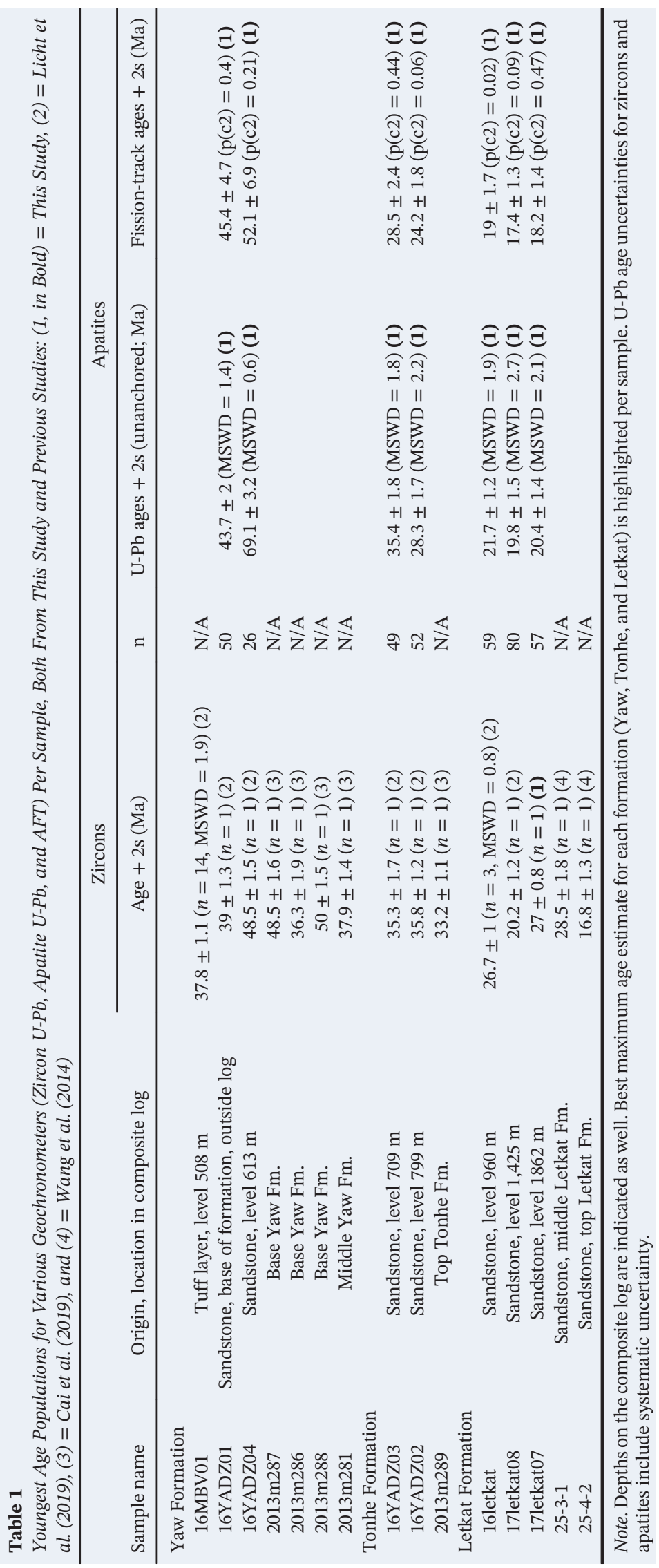


late Eocene thrusting in the Eastern Himalayan collision zone north of the IBR (Haproff et al., 2020), which these studies also attributed to the India-Asia collision. This together leads us to propose that the latest Eocene-middle Oligocene unconformity from this study was induced by the onset of the collision of India and Greater Burma with Asia in the Eastern Himalayas.

Furthermore, plate reconstructions suggest that deformation associated with this collision would have propagated from north to south starting in the late Eocene (Figure 11a; Morley et al., 2020; Westerweel et al., 2019). This fits with the late Eocene setting of the IBR with ongoing continental collision in the northern IBR (Aitchison et al., 2019), incipient emergence of the central IBR (Licht et al., 2019; this study), and no or only localized uplift in the southern IBR (Gough et al., 2020). It also fits with the prevailing marine conditions and ongoing subsidence in the Minbu Basin (Gough et al., 2020; Zhang et al., 2019), in contrast to the latest Eocene-middle Oligocene unconformity to the north (this study). This southward propagating collision event in the BT and Eastern Himalayas is consistent with our proposition that the source for the Yaw Formation includes WPA rocks that were presumably exhuming farther north in the Greater Burma region that has now disappeared in the collision zone (section 5.3.1). This northern extent of the BT would have entered the collision zone in the late Eocene as part of the Trans-Tethyan Arc, while the majority of the BT comprising the CMB farther south was still separated from the Asian margin (Figure 11a; Morley et al., 2020).

\subsection{Late Oligocene-Early Miocene Unconformity}

The latest Oligocene-early Miocene unconformity is characterized by significant changes in sedimentary facies, provenance, magnetic properties, and mineralogy. Notably, there are abrupt shifts toward late Oligocene-early Miocene zircon U-Pb and apatite U-Pb maximum depositional ages (Table S1), early Miocene AFT ages (Figure 10), and braided river sandstones containing an abundance of metamorphic grains and detrital magnetite (Figures 3, 6, and 7). Furthermore, it corresponds to a basin-wide late Oligocene angular unconformity on seismic lines (Zhang et al., 2017). The unconformity is coeval with pronounced exhumation in the IBR (Najman et al., 2020) as well as in the northern segment of the WPA (Li et al., 2013; Zhang et al., 2017, 2019), indicative of a major deformation event. This period is a time of important regional deformation and drainage reorganization across the entire Himalayan orogen, particularly around the Eastern Himalayan Syntaxis (Garzanti, 2019; Godin et al., 2006; Haproff et al., 2019; Kellett et al., 2013; Najman et al., 2019; Vannay et al., 2004), leading to the development of the modern Himalayan drainage systems (Bracciali et al., 2015). In the Chindwin Basin, the early Miocene Letkat Formation records the first clear sediment input from rapidly exhuming, deeply buried metamorphosed rocks of the Eastern Himalayan Syntaxis, evidenced by the appearance of early Miocene apatite U-Pb and AFT ages recording short lag times (section 5.3.3), as well as sandstones rich in high-grade metamorphic grains.

Plate tectonic reconstructions (Figure 11b; Morley et al., 2020; Rangin, 2018; Westerweel et al., 2019) show that the entire BT is indenting the Eastern Himalayan collision zone at the onset of the Miocene, squeezed in between India and the Asian margin during its ongoing northward motion. Therefore, we propose that the latest Oligocene to early Miocene unconformity constrained by this study is the result of this indentation, enhancing orogenic build-up at the collision front, with shortening within the BT and potential underthrusting of the Greater Burma region. This caused major uplift and exhumation in the Eastern Himalayan orogen and the BT, notably the MMMB and the WPA (Godin et al., 2006; Kellett et al., 2013; Li et al., 2013; Najman et al., 2019; Zhang et al., 2017), providing the dual sourcing of the Letkat Formation. Interestingly, plate reconstructions show a similar timing of southeast-directed extrusion of tectonic blocks away from the Eastern Himalayan Syntaxis, such as the Tengchong and Baoshan blocks (Li et al., 2018; Tong et al., 2013; Westerweel et al., 2019). This is also coeval with phases of extrusion-related exhumation and shearing in the northern MMMB (Bertrand et al., 2001; Bertrand \& Rangin, 2003). We suggest that these events could be a consequence of ongoing indentation of the BT (Figure 11b). These events would have slowed down the motion of the BT relative to India, leading to more pronounced dextral strike-slip faulting in the IBR during the Neogene (Rangin, 2018; Rangin et al., 2013).

\section{Conclusions}

Our new results from the late Eocene to early Miocene sedimentary infill of the Chindwin Basin in the Burmese forearc constrain two unconformities that reveal a two-stage interaction of the BT with the 
Asian margin during its northward motion alongside India. Observations from sedimentary facies and magnetic mineralogy show that the first unconformity between the late Eocene Yaw Formation and late Oligocene Tonhe Formation marks the transition of an anoxic estuarian to a purely fluvial depositional environment, alongside a larger contribution of reworked grains in the sediments. This first unconformity was determined to be of latest Eocene-middle Oligocene age, using a combination of magnetostratigraphy and the appearance of $\sim 29-24$ Ma AFT maximum depositional ages in the Tonhe Formation. Furthermore, our magnetostratigraphic results infer rapid $\sim 0.6 \mathrm{~m} / \mathrm{ky}$ subsidence of the Chindwin Basin during deposition of the Yaw Formation. Cessation of subsidence recorded by the first unconformity was likely induced by the initial collision of India, including the Greater Burma region (the northern extension of the BT) and the northern IBR, with the Asia margin. Both the Yaw and Tonhe Formations have a differing zircon age record compared to the WPA directly east of the Chindwin Basin, suggesting that the exhuming northern extension of the WPA in the Greater Burma region was an additional source region throughout the Eocene and Oligocene.

The second unconformity of late Oligocene-early Miocene age is characterized by an abrupt shift toward braided river sandstones rich in high-grade metamorphic grains and detrital magnetite, as well as the appearance of early Miocene ( 20-17 Ma) zircon U-Pb, apatite U-Pb, and AFT ages. Short lag times of $\sim 2 \mathrm{Ma}$ between the apatite $\mathrm{U}-\mathrm{Pb}$ and AFT ages record rapid exhumation identical to major phases of thrusting, exhumation, and extrusion in the Eastern Himalayan orogen and MMMB north of the BT. Furthermore, this unconformity can be traced across the BT and corresponds to a phase of uplift and exhumation of the WPA. Hence, this regional deformation phase is interpreted to result from the entire BT indenting the Eastern Himalayan collision zone. Our findings support recent plate reconstructions showing that the BT was part of a Trans-Tethyan Arc and moved at least 2,000 km northward alongside India since the late Eocene.

\section{Data Availability Statement}

Raw data and additional files supporting our analyses and conclusions are in the Supporting Information, separate supporting figure and table files, and are also available in the Mendeley Data repository at https://doi.org/10.17632/2rmg5yw78k.1 (Westerweel, 2020).

\section{Acknowledgments}

This research was primarily funded by the ERC Consolidator Grant MAGIC 649081 to Guillaume Dupont-Nivet. We would like to thank Catherine Kissel for the use of the AGM magnetometer at the LSCE paleomagnetic laboratory, France. Furthermore, we thank Loic Joanny and Francis Gouttefangeas for their help with SEM data. We thank P. Cullerier and A. Bernard for helping with the paleomagnetic experiments. We are grateful to François Guillocheau, Amy Gough, Erwan Hallot, France Lagroix, Andrew Mitchell, Chris Morley, Robert Morley, Pavel Pitra, Claude Rangin, and Anne Replumaz for helpful discussions during this study. Finally, we would like to thank Rishav Mallick and Paul Betka for constructive reviewing of this manuscript.

\section{References}

Acharyya, S. K. (2007). Collisional emplacement history of the Naga-Andaman ophiolites and the position of the eastern Indian suture. Journal of Asian Earth Sciences, 29(2-3), 229-242. https://doi.org/10.1016/j.jseaes.2006.03.003

Acharyya, S. K. (2015). Indo-Burma Range: A belt of accreted microcontinents, ophiolites and Mesozoic-Paleogene flyschoid sediments. International Journal of Earth Sciences, 104(5), 1235-1251. https://doi.org/10.1007/s00531-015-1154-6

Aitchison, J. C., Ali, J. R., \& Davis, A. M. (2007). When and where did India and Asia collide? Journal of Geophysical Research, 112 , B05423. https://doi.org/10.1029/2006JB004706

Aitchison, J. C., Ao, A., Bhowmik, S., Clarke, G. L., Ireland, T. R., Kachovich, S., et al. (2019). Tectonic evolution of the western margin of the Burma microplate based on new fossil and radiometric age constraints. Tectonics, 38, 2018TC005049. https://doi.org/10.1029/ 2018TC005049

Anthony, E. J., Lang, J., \& Oyédé, L. M. (1996). Sedimentation in a tropical, microtidal, wave-dominated coastal-plain estuary. Sedimentology, 43(4), 665-675. https://doi.org/10.1111/j.1365-3091.1996.tb02019.x

Arboit, F., Min, M., Chew, D., Mitchell, A., Drost, K., Badenszki, E., \& Daly, J. S. (2020). Constraining the links between the Himalayan belt and the Central Myanmar Basins during the Cenozoic: An integrated multi-proxy detrital geochronology and trace-element geochemistry study. Geoscience Frontiers, S1674987120301705. https://doi.org/10.1016/j.gsf.2020.05.024

Bannert, D., Sang Lyen, A., \& Htay, T. (2012). The geology of the Indoburman Ranges in Myanmar.

Barley, M. E., \& Zaw, K. (2009). SHRIMP U-Pb in zircon geochronology of granitoids from Myanmar: Temporal constraints on the tectonic evolution of Southeast Asia. In EGU General Assembly Conference Abstracts (Vol. 11, p. 3842).

Bender, F. (1983). Geology of Burma (p. 293). Berlin: Gebrüder Borntraeger.

Bertrand, G., \& Rangin, C. (2003). Tectonics of the western margin of the Shan plateau (central Myanmar): Implication for the IndiaIndochina oblique convergence since the Oligocene. Journal of Asian Earth Sciences, 21(10), 1139-1157. https://doi.org/10.1016/S13679120(02)00183-9

Bertrand, G., Rangin, C., Maluski, H., \& Bellon, H. (2001). Diachronous cooling along the Mogok Metamorphic Belt (Shan scarp, Myanmar): The trace of the northward migration of the Indian syntaxis. Journal of Asian Earth Sciences, 19(5), 649-659. https://doi.org/ 10.1016/S1367-9120(00)00061-4

Betka, P. M., Seeber, L., Thomson, S. N., Steckler, M. S., Sincavage, R., \& Zoramthara, C. (2018). Slip-partitioning above a shallow, weak décollement beneath the Indo-Burman accretionary prism. Earth and Planetary Science Letters, 503, 17-28. https://doi.org/10.1016/j. epsl.2018.09.003

Botev, Z. I., Grotowski, J. F., \& Kroese, D. P. (2010). Kernel density estimation via diffusion. The annals of Statistics, 38(5), $2916-2957$.

Bracciali, L., Najman, Y., Parrish, R. R., Akhter, S. H., \& Millar, I. (2015). The Brahmaputra tale of tectonics and erosion: Early Miocene river capture in the Eastern Himalaya. Earth and Planetary Science Letters, 415, 25-37. https://doi.org/10.1016/j.epsl.2015.01.022 
Bracciali, L., Parrish, R. R., Najman, Y., Smye, A., Carter, A., \& Wijbrans, J. R. (2016). Plio-Pleistocene exhumation of the eastern Himalayan syntaxis and its domal 'pop-up'. Earth-Science Reviews, 160, 350-385. https://doi.org/10.1016/j.earscirev.2016.07.010 Brunnschweiler, R. O. (1966). On the geology of the Indoburman ranges: (Arakan Coast and Yoma, Chin Hills, Naga Hills). Journal of the Geological Society of Australia, 13(1), 137-194. https://doi.org/10.1080/00167616608728608

Cai, F., Ding, L., Zhang, Q., Orme, D. A., Wei, H., Li, J., et al. (2019). Initiation and evolution of forearc basins in the Central Myanmar Depression. GSA Bulletin, 132, 1066-1082. https://doi.org/10.1130/B35301.1

Chew, D. M., Petrus, J. A., \& Kamber, B. S. (2014). U-Pb LA-ICPMS dating using accessory mineral standards with variable common Pb. Chemical Geology, 363, 185-199. https://doi.org/10.1016/j.chemgeo.2013.11.006

Chew, D. M., Sylvester, P. J., \& Tubrett, M. N. (2011). U-Pb and Th-Pb dating of apatite by LA-ICPMS. Chemical Geology, 280(1-2), 200-216. https://doi.org/10.1016/j.chemgeo.2010.11.010

Cogné, N., Chew, D. M., Donelick, R. A., \& Ansberque, C. (2020). LA-ICP-MS apatite fission track dating: A practical zeta-based approach. Chemical Geology, 531, 119302. https://doi.org/10.1016/j.chemgeo.2019.119302

Donelick, R. A., O'Sullivan, P. B., \& Ketcham, R. A. (2005). Apatite fission-track analysis. Reviews in Mineralogy and Geochemistry, 58(1), 49-94. https://doi.org/10.2138/rmg.2005.58.3

Dupont-Nivet, G., Krijgsman, W., Langereis, C. G., Abels, H. A., Dai, S., \& Fang, X. (2007). Tibetan plateau aridification linked to global cooling at the Eocene-Oligocene transition. Nature, 445(7128), 635-638. https://doi.org/10.1038/nature05516

Fareeduddin, A., \& Dilek, Y. (2015). Structure and petrology of the Nagaland-Manipur Hill ophiolitic mélange zone. NE India: A Fossil Tethyan Subduction Channel at the India-Burma Plate Boundary. Episodes, 38, 298-314.

Fisher, R. (1953). Dispersion on a sphere. Proceedings of the Royal Society of London Series A: Mathematical and Physical Sciences, 217(1130), 295-305.

Gardiner, N. J., Hawkesworth, C. J., Robb, L. J., Whitehouse, M. J., Roberts, N. M. W., Kirkland, C. L., \& Evans, N. J. (2017). Contrasting granite metallogeny through the zircon record: A case study from Myanmar. Scientific Reports, 7, 748, https://doi.org/10.1038/s41598017-00832-2

Gardiner, N. J., Searle, M. P., Morley, C. K., Robb, L. J., Whitehouse, M. J., Roberts, N. M. W., et al. (2018). The crustal architecture of Myanmar imaged through zircon U-Pb, Lu-Hf and O isotopes: Tectonic and metallogenic implications. Gondwana Research, 62, 27-60 https://doi.org/10.1016/j.gr.2018.02.008

Garzanti, E. (2019). The Himalayan Foreland Basin from collision onset to the present: A sedimentary-petrology perspective. Geological Society, London, Special Publications, 483, 65-122. https://doi.org/10.1144/SP483.17

Garzanti, E., Wang, J.-G., Vezzoli, G., \& Limonta, M. (2016). Tracing provenance and sediment fluxes in the Irrawaddy River basin (Myanmar). Chemical Geology, 440, 73-90. https://doi.org/10.1016/j.chemgeo.2016.06.010

Ghose, N. C., Chatterjee, N., \& Fareeduddin (2014). A Petrographic Atlas of Ophiolite: An example from the eastern India-Asia collision zone (p. 234). New Delhi: Springer.

Godin, L., Grujic, D., Law, R. D., \& Searle, M. P. (2006). Channel flow, ductile extrusion and exhumation in continental collision zones: An introduction. Geological Society, London, Special Publications, 268(1), 1-23. https://doi.org/10.1144/GSL.SP.2006.268.01.01

Gough, A., Hall, R., \& BouDagher-Fadel, M. K. (2020). Mid-Cenozoic fluvio-deltaic to marine environments of the Salin Sub-basin, Central Myanmar. Journal of Asian Earth Sciences, 104143. https://doi.org/10.1016/j.jseaes.2019.104143

Haproff, P. J., Odlum, M. L., Zuza, A. V., Yin, A., \& Stockli, D. F. (2020). Structural and thermochronologic constraints on the cenozoic tectonic development of the northern Indo-Burma Ranges. Tectonics, 39, e2020TC006231. https://doi.org/10.1029/2020TC006231

Haproff, P. J., Zuza, A. V., Yin, A., Harrison, T. M., Manning, C. E., Dubey, C. S., et al. (2019). Geologic framework of the northern IndoBurma Ranges and lateral correlation of Himalayan-Tibetan lithologic units across the eastern Himalayan syntaxis. Geosphere, 15, 856-881. https://doi.org/10.1130/GES02054.1

Hu, X., Garzanti, E., Moore, T., \& Raffi, I. (2015). Direct stratigraphic dating of India-Asia collision onset at the Selandian (middle Paleocene, 59 \pm 1 Ma). Geology, 43, 859-862. https://doi.org/10.1130/G36872.1

Huang, H., Morley, R., Licht, A., Dupont-Nivet, G., Grímsson, F., Zetter, R., et al. (2020). Eocene palms from central Myanmar in a South-East Asian and global perspective: Evidence from the palynological record. Botanical Journal of the Linnean Society, 194, 177-206. https://doi.org/10.1093/botlinnean/boaa038

Jaeger, J.-J., Thein, T., Benammi, M., Chaimanee, Y., Soe, A. N., Lwin, T., et al. (1999). A new primate from the middle Eocene of Myanmar and the Asian early origin of anthropoids. Science, 286(5439), 528-530. https://doi.org/10.1126/science.286.5439.528

Jagoutz, O., Royden, L., Holt, A. F., \& Becker, T. W. (2015). Anomalously fast convergence of India and Eurasia caused by double subduction. Nature Geoscience, 8(6), 475-478, https://doi.org/10.1038/ngeo2418

Kapp, P., \& DeCelles, P. G. (2019). Mesozoic-Cenozoic geological evolution of the Himalayan-Tibetan orogen and working tectonic hypotheses. American Journal of Science, 319(3), 159-254. https://doi.org/10.2475/03.2019.01

Kellett, D. A., Grujic, D., Coutand, I., Cottle, J., \& Mukul, M. (2013). The south Tibetan detachment system facilitates ultra rapid cooling of granulite-facies rocks in Sikkim Himalaya. Tectonics, 32, 252-270. https://doi.org/10.1002/tect.20014

Khin, K. (1999). Marine transgression and regression in Miocene sequences of northern Pegu (Bago) Yoma, central Myanmar. Journal of Asian Earth Sciences, 17(3), 369-393. https://doi.org/10.1016/S0743-9547(98)00065-8

Kirschvink, J. L. (1980). The least-squares line and plane and the analysis of palaeomagnetic data. Geophysical Journal International, 62(3), 699-718. https://doi.org/10.1111/j.1365-246X.1980.tb02601.x

Kissel, C., Barrier, E., Laj, C., \& Lee, T.-Q. (1986). Magnetic fabric in "undeformed” marine clays from compressional zones. Tectonics, 5(5), 769-781. https://doi.org/10.1029/TC005i005p00769

Lang, K. A., Huntington, K. W., Burmester, R., \& Housen, B. (2016). Rapid exhumation of the eastern Himalayan syntaxis since the late Miocene. Bulletin, 128, 1403-1422. https://doi.org/10.1130/b31419.1

Leeder, M. R. (2009). Sedimentology and sedimentary basins: from turbulence to tectonics. Chichester: John Wiley \& Sons.

Li, R., Mei, L., Zhu, G., Zhao, R., Xu, X., Zhao, H., et al. (2013). Late mesozoic to cenozoic tectonic events in volcanic arc, West Burma Block: Evidences from U-Pb zircon dating and apatite fission track data of granitoids. Journal of Earth Science, 24, 553-568. https://doi.org/ 10.1007/s12583-013-0349-7

Li, S., van Hinsbergen, D. J. J., Deng, C., Advokaat, E. L., \& Zhu, R. (2018). Paleomagnetic constraints from the Baoshan area on the deformation of the Qiangtang-Sibumasu terrane around the eastern Himalayan syntaxis. Journal of Geophysical Research: Solid Earth, 123, 977-997. https://doi.org/10.1002/2017JB015112

Licht, A., Boura, A., De Franceschi, D., Utescher, T., Sein, C., \& Jaeger, J.-J. (2015). Late middle Eocene fossil wood of Myanmar: Implications for the landscape and the climate of the Eocene Bengal Bay. Review of Palaeobotany and Palynology, 216, 44-54. https://doi. org/10.1016/j.revpalbo.2015.01.010 
Licht, A., Cojan, I., Caner, L., Soe, A. N., Jaeger, J.-J., \& France-Lanord, C. (2014). Role of permeability barriers in alluvial hydromorphic palaeosols: The Eocene Pondaung Formation, Myanmar. Sedimentology, 61(2), 362-382. https://doi.org/10.1111/sed.12059

Licht, A., Dupont-Nivet, G., Win, Z., Swe, H. H., Kaythi, M., Roperch, P., et al. (2019). Paleogene evolution of the Burmese forearc basin and implications for the history of India-Asia convergence. Geological Society of America Bulletin, 1(130), 20. https://doi.org/10.1130/ B35002.1

Licht, A., France-Lanord, C., Reisberg, L., Fontaine, C., Soe, A. N., \& Jaeger, J.-J. (2013). A palaeo Tibet-Myanmar connection? Reconstructing the Late Eocene drainage system of central Myanmar using a multi-proxy approach. Journal of the Geological Society, 170, 929-939. https://doi.org/10.1144/jgs2012-126

Licht, A., van Cappelle, M., Abels, H. A., Ladant, J.-B., Trabucho-Alexandre, J., France-Lanord, C., et al. (2014). Asian monsoons in a late Eocene greenhouse world. Nature, 513, 501-506. https://doi.org/10.1038/nature13704

Licht, A., Win, Z., Westerweel, J., Cogné, N., Morley, C., Chantraprasert, S., et al. (2020). Magmatic history of central Myanmar and implications for the evolution of the Burma Terrane. Gondwana Research, 87, 303-319. https://doi.org/10.1016/j.gr.2020.06.016

Lin, T.-H., Mitchell, A. H. G., Chung, S.-L., Tan, X.-B., Tang, J.-T., Oo, T., \& Wu, F.-Y. (2019). Two parallel magmatic belts with contrasting isotopic characteristics from southern Tibet to Myanmar: Zircon U-Pb and Hf isotopic constraints. Journal of the Geological Society, 176, 574-587. https://doi.org/10.1144/jgs2018-072

Liu, C.-Z., Chung, S.-L., Wu, F.-Y., Zhang, C., Xu, Y., Wang, J.-G., et al. (2016). Tethyan suturing in Southeast Asia: Zircon U-Pb and Hf-O isotopic constraints from Myanmar ophiolites. Geology, 44, 311-314. https://doi.org/10.1130/G37342.1

Ludwig, K. R. (2003). User's manual for isoplot 3.00, a geochronological toolkit for Microsoft Excel, Special Publication (Vol. 4, pp. 25-32). Berkeley: Berkeley Geochronology Center.

Lwin, S. M., Thu, S. S., Aung, M. M., Khine, K. K., Aung, H., Thidar, M., \& Pau, S. K. (2017). Paleo-environment of the Miocene sediments, Central Belt, Myanmar.

Matthews, W. A., \& Guest, B. (2017). A practical approach for collecting large- $n$ detrital zircon U-Pb data sets by quadrupole LA-ICP-MS. Geostandards and Geoanalytical Research, 41, 161-180. https://doi.org/10.1111/ggr.12146

Maurin, T., \& Rangin, C. (2009). Structure and kinematics of the Indo-Burmese Wedge: Recent and fast growth of the outer wedge: Growth of the outer Indo-Burmese wedge. Tectonics, 28, TC2010. https://doi.org/10.1029/2008TC002276

Mitchell, A. (2017). Geological belts, plate boundaries, and mineral deposits in Myanmar. Oxford: Elsevier.

Mitchell, A., Chung, S.-L., Oo, T., Lin, T.-H., \& Hung, C.-H. (2012). Zircon U-Pb ages in Myanmar: Magmatic-metamorphic events and the closure of a neo-Tethys ocean? Journal of Asian Earth Sciences, 56, 1-23. https://doi.org/10.1016/j.jseaes.2012.04.019

Morley, C. K. (2009). Evolution from an oblique subduction back-arc mobile belt to a highly oblique collisional margin: The Cenozoic tectonic development of Thailand and eastern Myanmar. Geological Society, London, Special Publications, 318(1), 373-403. https://doi. org/10.1144/SP318.14

Morley, C. K. (2017). Syn-kinematic sedimentation at a releasing splay in the northern Minwun Ranges, Sagaing Fault zone, Myanmar: Significance for fault timing and displacement. Basin Research, 29, 684-700. https://doi.org/10.1111/bre.12201

Morley, C. K., \& Arboit, F. (2019). Dating the onset of motion on the Sagaing fault: Evidence fromdetrital zircon and titanite U-Pb geochronology from the NorthMinwun Basin, Myanmar. Geology, 47, 581-585. https://doi.org/10.1130/G46321.1

Morley, C. K., Naing, T. T., Searle, M., \& Robinson, S. A. (2020). Structural and tectonic development of the Indo-Burma ranges. EarthScience Reviews, 200, 102992. https://doi.org/10.1016/j.earscirev.2019.102992

Müller, R. D., Cannon, J., Qin, X., Watson, R. J., Gurnis, M., Williams, S., et al. (2018). GPlates: Building a virtual Earth through deep time. Geochemistry, Geophysics, Geosystems, 19, 2243-2261. https://doi.org/10.1029/2018GC007584

Müller, R. D., Zahirovic, S., Williams, S. E., Cannon, J., Seton, M., Bower, D. J., \& Gurnis, M. (2019). A global plate model including lithospheric deformation along major rifts and orogens since the Triassic. Tectonics, 38, 1884-1907. https://doi.org/10.1029/ 2018TC005462

Naing, T. T., Bussien, D. A., Winkler, W. H., Nold, M., \& Von Quadt, A. (2014). Provenance study on Eocene-Miocene sandstones of the Rakhine Coastal Belt, Indo-Burman Ranges of Myanmar: Geodynamic implications. Geological Society, London, Special Publications, 386, 195-216. https://doi.org/10.1144/SP386.10

Najman, Y., Allen, R., Willett, E. A. F., Carter, A., Barfod, D., Garzanti, E., et al. (2012). The record of Himalayan erosion preserved in the sedimentary rocks of the Hatia Trough of the Bengal Basin and the Chittagong Hill Tracts, Bangladesh. Basin Research, 24(5), 499-519. https://doi.org/10.1111/j.1365-2117.2011.00540.x

Najman, Y., Mark, C., Barfod, D. N., Carter, A., Parrish, R., Chew, D., \& Gemignani, L. (2019). Spatial and temporal trends in exhumation of the Eastern Himalaya and syntaxis as determined from a multitechnique detrital thermochronological study of the Bengal Fan. GSA Bulletin, 131, 1607-1622. https://doi.org/10.1130/B35031.1

Najman, Y., Sobel, E. R., Millar, I., Stockli, D. F., Govin, G., Lisker, F., et al. (2020). The exhumation of the Indo-Burman Ranges, Myanmar. Earth and Planetary Science Letters, 530, 115948. https://doi.org/10.1016/j.epsl.2019.115948

Nielsen, C., Chamot-Rooke, N., \& Rangin, C. (2004). From partial to full strain partitioning along the Indo-Burmese hyper-oblique subduction. Marine Geology, 209(1-4), 303-327. https://doi.org/10.1016/j.margeo.2004.05.001

Ogg, J. G., Ogg, G., \& Gradstein, F. M. (2016). A concise geologic time scale. Oxford: Elsevier.

Paton, C., Woodhead, J. D., Hellstrom, J. C., Hergt, J. M., Greig, A., \& Maas, R. (2010). Improved laser ablation U-Pb zircon geochronology through robust downhole fractionation correction. Geochemistry, Geophysics, Geosystems, 11, Q0AA06. https://doi.org/10.1029/ 2009GC002618

Pivnik, D. A., Nahm, J., Tucker, R. S., Smith, G. O., Nyein, K., Nyunt, M., \& Maung, P. H. (1998). Polyphase deformation in a fore-arc/backarc basin, Salin Subbasin, Myanmar (Burma). AAPG Bulletin, 82(10), 1837-1856.

Rangin, C. (2018). The western Sunda basins and the India/Asia collision: An atlas. Paris, France: Geotecto.

Rangin, C., Maurin, T., \& Masson, F. (2013). Combined effects of Eurasia/Sunda oblique convergence and East-Tibetan crustal flow on the active tectonics of Burma. Journal of Asian Earth Sciences, 76, 185-194. https://doi.org/10.1016/j.jseaes.2013.05.018

Replumaz, A., Guillot, S., Villaseñor, A., \& Negredo, A. M. (2013). Amount of Asian lithospheric mantle subducted during the India/Asia collision. Gondwana Research, 24, 936-945. https://doi.org/10.1016/j.gr.2012.07.019

Replumaz, A., Negredo, A. M., Guillot, S., \& Villaseñor, A. (2010). Multiple episodes of continental subduction during India/Asia convergence: Insight from seismic tomography and tectonic reconstruction. Tectonophysics, 483(1-2), 125-134. https://doi.org/10.1016/j. tecto.2009.10.007

Retallack, G. J. (2008). Soils of the past: An introduction to paleopedology. Chichester: John Wiley \& Sons.

Roberts, A. P. (2015). Magnetic mineral diagenesis. Earth-Science Reviews, 151, 1-47. https://doi.org/10.1016/j.earscirev.2015.09.010 
Rochette, P. (1988). Inverse magnetic fabric in carbonate-bearing rocks. Earth and Planetary Science Letters, 90(2), 229-237. https://doi.org/ 10.1016/0012-821X(88)90103-3

Roperch, P., \& Taylor, G. K. (1986). The importance of gyromagnetic remanence in alternating field demagnetization. Some new data and experiments on GRM and RRM. Geophysical Journal International, 87(3), 949-965. https://doi.org/10.1111/j.1365-246X.1986. tb01978.x

Royden, L. H., Burchfiel, B. C., \& van der Hilst, R. D. (2008). The geological evolution of the Tibetan Plateau. Science, 321(5892), 1054-1058. https://doi.org/10.1126/science.1155371

Searle, M. P., Garber, J. M., Hacker, B. R., Htun, K., Gardiner, N. J., Waters, D. J., \& Robb, L. J. (2020). Timing of syenite-charnockite magmatism and ruby-and sapphire metamorphism in the Mogok valley region, Myanmar. Tectonics, 39, e2019TC005998. https://doi. org/10.1029/2019TC005998

Searle, M. P., Morley, C. K., Waters, D. J., Gardiner, N. J., Htun, U. K., Than Than, N., \& Robb, L. J. (2017). Chapter 12. Tectonic and metamorphic evolution of the Mogok Metamorphic and Jade Mines belts and ophiolitic terranes of Burma (Myanmar). Geological Society, London, Memoirs, 48, 261-293. https://doi.org/10.1144/M48.12

Searle, M. P., Noble, S. R., Cottle, J. M., Waters, D. J., Mitchell, A. H. G., Hlaing, T., \& Horstwood, M. S. A. (2007). Tectonic evolution of the Mogok metamorphic belt, Burma (Myanmar) constrained by U-Th-Pb dating of metamorphic and magmatic rocks: U-Th- $\mathrm{Pb}$ ages of Mogok belt. Tectonics, 26, TC3014. https://doi.org/10.1029/2006TC002083

Shen, F., Royden, L. H., \& Burchfiel, B. C. (2001). Large-scale crustal deformation of the Tibetan Plateau. Journal of Geophysical Research, 106(B4), 6793-6816. https://doi.org/10.1029/2000JB900389

Singh, A. K., Khogenkumar, S., Singh, L. R., Bikramaditya, R. K., Khuman, C. M., \& Thakur, S. S. (2016). Evidence of mid-ocean ridge and shallow subduction forearc magmatism in the Nagaland-Manipur ophiolites, northeast India: Constraints from mineralogy and geochemistry of gabbros and associated mafic dykes. Geochemistry, 76, 605-620. https://doi.org/10.1016/j.chemer.2016.09.002

Smith, J. J., Hasiotis, S. T., Kraus, M. J., \& Woody, D. T. (2008). Naktodemasis bowni: New ichnogenus and ichnospecies for adhesive meniscate burrows (AMB), and paleoenvironmental implications, Paleogene Willwood Formation, Bighorn Basin, Wyoming. Journal of Paleontology, 82(2), 267-278. https://doi.org/10.1666/06-023.1

Socquet, A., Vigny, C., Chamot-Rooke, N., Simons, W., Rangin, C., \& Ambrosius, B. (2006). India and Sunda plates motion and deformation along their boundary in Myanmar determined by GPS: GPS India-Sunda Motion, Myanmar Strain. Journal of Geophysical Research, 111, B05406. https://doi.org/10.1029/2005JB003877

Stacey, J. T., \& Kramers, J. D. (1975). Approximation of terrestrial lead isotope evolution by a two-stage model. Earth and Planetary Science Letters, 26(2), 207-221. https://doi.org/10.1016/0012-821X(75)90088-6

Steckler, M. S., Akhter, S. H., \& Seeber, L. (2008). Collision of the Ganges-Brahmaputra Delta with the Burma Arc: Implications for earthquake hazard. Earth and Planetary Science Letters, 273(3-4), 367-378. https://doi.org/10.1016/j.epsl.2008.07.009

Tang, D., Shi, X., Jiang, G., Wu, T., Ma, J., \& Zhou, X. (2018). Stratiform siderites from the Mesoproterozoic Xiamaling Formation in North China: Genesis and environmental implications. Gondwana Research, 58, 1-15. https://doi.org/10.1016/j.gr.2018.01.013

Tauxe, L. (2010). Essentials of paleomagnetism. Los Angeles: University of California Press.

Thein, M., \& Maung, M. (2017). The Eastern (back-arc) Basin of Central Myanmar: Basement rocks, lithostratigraphic units, palaeocurrents, provenance and developmental history. Geological Society, London, Memoirs, 48, 169-183. https://doi.org/10.1144/M48.8

Tong, Y.-B., Yang, Z., Zheng, L.-D., Xu, Y.-L., Wang, H., Gao, L., \& Hu, X.-Z. (2013). Internal crustal deformation in the northern part of Shan-Thai Block: New evidence from paleomagnetic results of cretaceous and Paleogene redbeds. Tectonophysics, 608, $1138-1158$. https://doi.org/10.1016/j.tecto.2013.06.031

United Nations (1978). Geology and exploration geochemistry of the Pinlebu-Banmauk area, Sagaing Division, northern Burma. Technical Report No. 2. DP/UN/BUR-72-002. Geological Survey and Exploration Project, United Nations Development Programme, New York, 66

van der Beek, P., Govin, G., Najman, Y., Millar, I., Gemignani, L., Huyghe, P., et al. (2019). Early onset and late acceleration of rapid exhumation in the Namche Barwa syntaxis, eastern Himalaya. AGUFM, 2019, T54A-T07A.

van Hinsbergen, D. J. J., Kapp, P., Dupont-Nivet, G., Lippert, P. C., DeCelles, P. G., \& Torsvik, T. H. (2011). Restoration of Cenozoic deformation in Asia and the size of Greater India: Restoring Cenozoic Asian deformation. Tectonics, 30, TC5003. https://doi.org/ 10.1029/2011TC002908

van Hinsbergen, D. J. J., Lippert, P. C., Li, S., Huang, W., Advokaat, E. L., \& Spakman, W. (2018). Reconstructing Greater India: Paleogeographic, kinematic, and geodynamic perspectives. Tectonophysics, 760, 69-94. https://doi.org/10.1016/j.tecto.2018.04.006

Vannay, J.-C., Grasemann, B., Rahn, M., Frank, W., Carter, A., Baudraz, V., \& Cosca, M. (2004). Miocene to Holocene exhumation of metamorphic crustal wedges in the NW Himalaya: Evidence for tectonic extrusion coupled to fluvial erosion. Tectonics, 23 , TC1014. https://doi.org/10.1029/2002TC001429

Vérard, C., Stampfli, G., Borel, G., \& Hochard, C. (2017). The Indian promontory: A bridge between plate tectonics and life evolution models. Universal Journal of Geoscience, 5(2), 25-32. https://doi.org/10.13189/ujg.2017.050202

Vermeesch, P. (2013). Multi-sample comparison of detrital age distributions. Chemical Geology, 341, 140-146. https://doi.org/10.1016/j. chemgeo.2013.01.010

Vermeesch, P. (2018). IsoplotR: A free and open toolbox for geochronology. Geoscience Frontiers, 9, 1479-1493. https://doi.org/10.1016/j. gsf.2018.04.001

Wang, J.-G., Wu, F.-Y., Tan, X.-C., \& Liu, C.-Z. (2014). Magmatic evolution of the Western Myanmar Arc documented by U-Pb and Hf isotopes in detrital zircon. Tectonophysics, 612-613, 97-105. https://doi.org/10.1016/j.tecto.2013.11.039

Westerweel, J., Roperch, P., Licht, A., Dupont-Nivet, G., Win, Z., Poblete, F., et al. (2019). Burma Terrane part of the Trans-Tethyan arc during collision with India according to palaeomagnetic data. Nature Geoscience, 12, 863-868. https://doi.org/10.1038/s41561-019-0443-2

Westerweel, J. (2020). "Data for: Burma Terrane collision and northward indentation in the Eastern Himalayas recorded in the Eocene Miocene Chindwin Basin (Myanmar)”, Mendeley Data, V1, https://doi.org/10.17632/2rmg5yw78k.1

Woodhead, J. D., Hellstrom, J., Hergt, J. M., Greig, A., \& Maas, R. (2007). Isotopic and elemental imaging of geological materials by laser ablation inductively coupled plasma-mass spectrometry. Geostandards and Geoanalytical Research, 31(4), 331-343.

Yin, A., \& Harrison, T. M. (2000). Geologic evolution of the Himalayan-Tibetan Orogen. Annual Review of Earth and Planetary Sciences, 28(1), 211-280. https://doi.org/10.1146/annurev.earth.28.1.211

Yui, T.-F., Fukoyama, M., Iizuka, Y., Wu, C.-M., Wu, T.-W., Liou, J. G., \& Grove, M. (2013). Is Myanmar jadeitite of Jurassic age? A result from incompletely recrystallized inherited zircon. Lithos, 160, 268-282. https://doi.org/10.1016/j.lithos.2012.12.011

Zat, M., \& Aung, D. W. (2018). Sedimentology and sequence stratigraphy of Letkat Formation in Kalewa-Mawleik Area, Sagaing Region 
Zaw, K., Meffre, S., Takai, M., Suzuki, H., Burrett, C., Htike, T., et al. (2014). The oldest anthropoid primates in SE Asia: Evidence from LAICP-MS U-Pb zircon age in the Late Middle Eocene Pondaung Formation, Myanmar. Gondwana Research, 26, 122-131. https://doi.org/ 10.1016/j.gr.2013.04.007

Zeitler, P. K., Meltzer, A. S., Brown, L., Kidd, W. S., Lim, C., \& Enkelmann, E. (2014). Tectonics and topographic evolution of Namche Barwa and the easternmost Lhasa block, Tibet. In Toward an improved understanding of uplift mechanisms and the elevation history of the Tibetan Plateau (Vol. 507, pp. 23-58). Boulder, CO: Geological Society of America Special Papers.

Zhang, P., Mei, L., Hu, X., Li, R., Wu, L., Zhou, Z., \& Qiu, H. (2017). Structures, uplift, and magmatism of the Western Myanmar Arc: Constraints to mid-Cretaceous-Paleogene tectonic evolution of the western Myanmar continental margin. Gondwana Research, 52, 18-38. https://doi.org/10.1016/j.gr.2017.09.002

Zhang, P., Najman, Y., Mei, L., Millar, I., Sobel, E. R., Carter, A., et al. (2019). Palaeodrainage evolution of the large rivers of East Asia, and Himalayan-Tibet tectonics. Earth-Science Reviews, 192, 601-630. https://doi.org/10.1016/j.earscirev.2019.02.003

Zijderveld, J. D. A. (1967). AC demagnetization of rocks: Analysis of results, methods in Paleomagnetism DW Collinson, KM Creer, SK Runcorn (pp. 254-286). New York: Elsevier.

\section{References From the Supporting Information}

Andersen, T. (2002). Correction of common lead in U-Pb analyses that do not report ${ }^{204} \mathrm{~Pb}$. Chemical Geology, 192(1-2), 59-79. https://doi. org/10.1016/S0009-2541(02)00195-X

Black, L. P., Kamo, S. L., Allen, C. M., Davis, D. W., Aleinikoff, J. N., Valley, J. W., et al. (2004). Improved ${ }^{206} \mathrm{~Pb} /{ }^{238} \mathrm{U}$ microprobe geochronology by the monitoring of a trace-element-related matrix effect; SHRIMP, ID-TIMS, ELA-ICP-MS and oxygen isotope documentation for a series of zircon standards. Chemical Geology, 205(1-2), 115-140. https://doi.org/10.1016/j.chemgeo.2004.01.003

Chew, D. M., Petrus, J. A., \& Kamber, B. S. (2014). U-Pb LA-ICPMS dating using accessory mineral standards with variable common Pb. Chemical Geology, 363, 185-199. https://doi.org/10.1016/j.chemgeo.2013.11.006

Cogné, N., Chew, D. M., Donelick, R. A., \& Ansberque, C. (2020). LA-ICP-MS apatite fission track dating: A practical zeta-based approach. Chemical Geology, 531, 119302. https://doi.org/10.1016/j.chemgeo.2019.119302

Eddy, M. P., Bowring, S. A., Miller, R. B., \& Tepper, J. H. (2016). Rapid assembly and crystallization of a fossil large-volume silicic magma chamber. Geology, 44(4), 331-334. https://doi.org/10.1130/G37631.1

Gehrels, G. E., Valencia, V. A., \& Ruiz, J. (2008). Enhanced precision, accuracy, efficiency, and spatial resolution of U-Pb ages by laser ablation-multicollector-inductively coupled plasma-mass spectrometry. Geochemistry, Geophysics, Geosystems, 9, Q03017. https://doi. org/10.1029/2007GC001805

Gehrels, G., Kapp, P., DeCelles, P., Pullen, A., Blakey, R., Weislogel, A., et al. (2011). Detrital zircon geochronology of pre-Tertiary strata in the Tibetan-Himalayan orogen. Tectonics, 30, TC5016. https://doi.org/10.1029/2011TC002868

Horstwood, M. S., Foster, G. L., Parrish, R. R., Noble, S. R., \& Nowell, G. M. (2003). Common-Pb corrected in situ U-Pb accessory mineral geochronology by LA-MC-ICP-MS. Journal of Analytical Atomic Spectrometry, 18(8), 837-846. https://doi.org/10.1039/B304365G

Horstwood, M. S., Košler, J., Gehrels, G., Jackson, S. E., McLean, N. M., Paton, C., et al. (2016). Community-derived standards for LA-ICPMS U-(Th-) Pb geochronology-Uncertainty propagation, age interpretation and data reporting. Geostandards and Geoanalytical Research, 40, 311-332. https://doi.org/10.1111/j.1751-908X.2016.00379.x

Jaffey, A. H., Flynn, K. F., Glendenin, L. E., Bentley, W. T., \& Essling, A. M. (1971). Precision measurement of half-lives and specific activities of ${ }^{235} \mathrm{U}$ and ${ }^{238} \mathrm{U}$. Physical Review C, 4(5), 1889-1906. https://doi.org/10.1103/PhysRevC.4.1889

Klepeis, K. A., Crawford, M. L., \& Gehrels, G. (1998). Structural history of the crustal-scale coast shear zone north of Portland Canal, southeast Alaska and British Columbia. Journal of Structural Geology, 20(7), 883-904. https://doi.org/10.1016/S0191-8141(98)00020-0

Košler, J., Sláma, J., Belousova, E., Corfu, F., Gehrels, G. E., Gerdes, A., et al. (2013). U-Pb detrital zircon analysis-Results of an inter-laboratory comparison. Geostandards and Geoanalytical Research, 37, 243-259. https://doi.org/10.1111/j.1751-908X.2013.00245.x

Licht, A., Dupont-Nivet, G., Win, Z., Swe, H. H., Kaythi, M., Roperch, P., et al. (2018). Paleogene evolution of the Burmese forearc basin and implications for the history of India-Asia convergence. GSA Bulletin, 131, 730-748. https://doi.org/10.1130/b35002.1

Matthews, W. A., \& Guest, B. (2017). A practical approach for collecting large- $n$ detrital zircon U-Pb data sets by quadrupole LA-ICP-MS Geostandards and Geoanalytical Research, 41, 161-180. https://doi.org/10.1111/ggr.12146

Mattinson, J. M. (1987). U-Pb ages of zircons: A basic examination of error propagation. Chemical Geology: Isotope Geoscience Section, 66(1-2), 151-162. https://doi.org/10.1016/0168-9622(87)90037-6

Mattinson, J. M. (2010). Analysis of the relative decay constants of ${ }^{235} \mathrm{U}$ and ${ }^{238} \mathrm{U}$ by multi-step CA-TIMS measurements of closed-system natural zircon samples. Chemical Geology, 275(3-4), 186-198. https://doi.org/10.1016/j.chemgeo.2010.05.007

McDowell, F. W., McIntosh, W. C., \& Farley, K. A. (2005). A precise ${ }^{40} \mathrm{Ar}-{ }^{39} \mathrm{Ar}$ reference age for the Durango apatite (U-Th)/He and fission-track dating standard. Chemical Geology, 214(3-4), 249-263. https://doi.org/10.1016/j.chemgeo.2004.10.002

Nemchin, A. A., \& Cawood, P. A. (2005). Discordance of the U-Pb system in detrital zircons: Implication for provenance studies of sedimentary rocks. Sedimentary Geology, 182(1-4), 143-162. https://doi.org/10.1016/j.sedgeo.2005.07.011

Paces, J. B., \& Miller, J. D. Jr. (1993). Precise U-Pb ages of Duluth complex and related mafic intrusions, northeastern Minnesota: Geochronological insights to physical, petrogenetic, paleomagnetic, and tectonomagmatic processes associated with the $1.1 \mathrm{Ga}$ midcontinent rift system. Journal of Geophysical Research, 98(B8), 13,997-14,013. https://doi.org/10.1029/93JB01159

Paton, C., Woodhead, J., Hellstrom, J., Hergt, J., Greig, A., \& Maas, R. (2010). Improved laser ablation U-Pb zircon geochronology through robust down-hole fractionation correction. Geochemistry, Geophysics, Geosystems, 11, Q0AA06. https://doi.org/10.1029/2009GC002618

Paton, C., Hellstrom, J., Paul, B., Woodhead, J., \& Hergt, J. (2011). Iolite: Freeware for the visualisation and processing of mass spectrometric data. Journal of Analytical Atomic Spectrometry, 26(12), 2508-2518. https://doi.org/10.1039/C1JA10172B

Pullen, A., Ibáñez-Mejia, M., Gehrels, G. E., Giesler, D., \& Pecha, M. (2018). Optimization of a laser ablation-single collector-inductively coupled plasma-mass spectrometer (Thermo Element 2) for accurate, precise, and efficient zircon U-Th-Pb geochronology. Geochemistry, Geophysics, Geosystems, 19, 3689-3705. https://doi.org/10.1029/2018GC007889

Schmitz, M. D., \& Bowring, S. A. (2001). U-Pb zircon and titanite systematics of the Fish Canyon Tuff: An assessment of high-precision U$\mathrm{Pb}$ geochronology and its application to young volcanic rocks. Geochimica et Cosmochimica Acta, 65(15), 2571-2587. https://doi.org/ 10.1016/S0016-7037(01)00616-0

Schoene, B., \& Bowring, S. A. (2006). U-Pb systematics of the McClure Mountain syenite: Thermochronological constraints on the age of the ${ }^{40} \mathrm{Ar} /{ }^{39} \mathrm{Ar}$ standard MMhb. Contributions to Mineralogy and Petrology, 151(5), 615-630. https://doi.org/10.1007/s00410-006-0077-4 
Sláma, J., Košler, J., Condon, D. J., Crowley, J. L., Gerdes, A., Hanchar, J. M., et al. (2008). Plešovice zircon-A new natural reference material for U-Pb and Hf isotopic microanalysis. Chemical Geology, 249(1-2), 1-35. https://doi.org/10.1016/j.chemgeo.2007.11.005

Spencer, C. J., Kirkland, C. L., \& Taylor, R. J. (2016). Strategies towards statistically robust interpretations of in situ U-Pb zircon geochronology. Geoscience Frontiers, 7, 581-589. https://doi.org/10.1016/j.gsf.2015.11.006

Spencer, C. J., Prave, A. R., Cawood, P. A., \& Roberts, N. M. (2014). Detrital zircon geochronology of the Grenville/Llano foreland and basal Sauk Sequence in west Texas, USA. GSA Bulletin, 126, 1117-1128. https://doi.org/10.1130/B30884.1

Stern, R. A., Bodorkos, S., Kamo, S. L., Hickman, A. H., \& Corfu, F. (2009). Measurement of SIMS instrumental mass fractionation of Pb isotopes during zircon dating. Geostandards and Geoanalytical Research, 33(2), 145-168. https://doi.org/10.1111/j.1751908X.2009.00023.X

Thomson, S. N., Gehrels, G. E., Ruiz, J., \& Buchwaldt, R. (2012). Routine low-damage apatite U-Pb dating using laser ablation-multicollector-ICPMS. Geochemistry, Geophysics, Geosystems, 13, Q0AA21. https://doi.org/10.1029/2011GC003928

Wiedenbeck, M. A. P. C., Alle, P., Corfu, F., Griffin, W. L., Meier, M., Oberli, F. V., et al. (1995). Three natural zircon standards for U-Th-Pb, Lu-Hf, trace element and REE analyses. Geostandards Newsletter, 19(1), 1-23. https://doi.org/10.1111/j.1751-908X.1995.tb00147.x

Woodhead, J., Hellstrom, J., Hergt, J., Greig, A., \& Maas, R. (2007). Isotopic and elemental imaging of geological materials by laser ablation inductively coupled plasma mass spectrometry. Journal of Geostandards and Geoanalytical Research, 31, 331-343. 